\title{
AKTIVITY KELTOV NA LOKALITÁCH Z DOBY POPOLNICOVÝCH POLÍ NA SLOVENSKU ${ }^{1}$
}

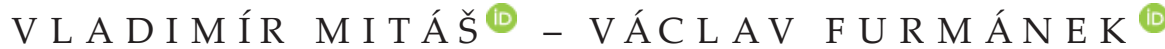

\begin{abstract}
The Celts' Activities at Sites of the Urnfield Period in Slovakia. The authors of the article analyse a remarkable phenomenon - occurrence of material from the La Tène period at sites of the Urnfield period. Their deeper interest in this topic follows from the stated sporadically presence of iron artifacts from the Late Iron Age at systematically excavated burial grounds of the South-eastern Urnfields in the area of Cinobaňa and Radzovce villages in the south of central Slovakia. However, traces of activities of historical Celts are also evident at cremation burial grounds of other contemporary cultures or in tumuli from the Late Bronze Age in other regions of Slovakia. Typical and often peculiar artifacts from the La Tène period also come from several upland sites and hillforts predominantly settled by the Urnfield culture or from the Early Iron Age. The authors not only try to present the studied finds selectively, they attempt to categorize, interprete and last but not least, compare them with similar material from the neighbouring countries.
\end{abstract}

Keywords: Slovakia, Urnfield period, La Tène period, burial grounds, hillforts, activities of the Celts.

\section{ÚVOD}

Aktivitami Keltov na pravekých lokalitách sa bližšie zaoberajú viaceré práce českých bádatelov (napr. Chytráček 1995; Jansová 1962; John 2003; Waldhauser 1999; 2001). V slovenskej archeologickej spisbe sa na nálezy a nálezové situácie, ktoré v tomto príspevku analyzujeme, upozornilo napr. už v súvislosti s hrobovým materiálom z doby laténskej v Ratke na juhu stredného Slovenska (Furmánek/ Sankot 1985, 273, 276). V uvedených prácach sa pojednáva spravidla o ojedinelých a zložito interpretovatelných nálezoch kovových a sklených predmetov, ale aj o keramike a minciach z doby laténskej, ktoré sa objavili na chronologicky starších žiarových pohrebiskách, v mohylách (mohylníkoch), či v areáloch výšinných sídiel s opevneniami (hradiskách). Osobitými nálezmi sú relevantné keltské hroby $\mathrm{v}$ násypoch pravekých mohýl alebo $\mathrm{v}$ prírodných útvaroch pripomínajúcich mohyly. V mnohých prípadoch sú uvádzané typy nálezísk datované práve do mladších stupňov doby bronzovej - obdobia popolnicových polí a do staršej doby železnej - halštatskej. V súčasnosti je už zrejmé, že laténske nálezy tejto kategórie nie sú iba regionálnym špecifikom v Česku, ale podstatne širším fenoménom keltskej archeológie, čo jasne potvrdzuje početný a neustále pribúdajúci archeologický materiál z oblasti severne od Álp vôbec (napr. Čižmářová/Stuchlík 2014, 471, 481; Chytráček a i. 2017a, 345-348, tamže aj d’alšia zahraničná literatúra k téme; John a i. 2015a, 13, 14; 2015b, 145, 146; Waldhauser 1999, 163).
Do uvedenej problematiky na území Slovenska sme vstúpili v súvislosti s výskytom artefaktov z mladšej doby železnej na pohrebisku kultúr juhovýchodných popolnicových polí v Cinobani (Furmánek/Mitáš 2011a; 2014) a po rokoch sa k tejto téme opät vraciame. Na nálezy a objekty z doby laténskej na lokalitách využívaných na pochovávanie, osídlených či inak používaných tažiskovo $\mathrm{v}$ dobe popolnicových polí a prípadne $\mathrm{v}$ dobe halštatskej, ktoré sa nedajú spolahlivo začlenit do radu stabilných sídlisk a pohrebísk zo stupňov LTA-D a ktoré v spisbe zastrešuje všeobecná kategória „ojedinelý nález“ alebo „ojedinelý hrob“, však slovenskí bádatelia v rôznych súvislostiach poukázali už pred objavmi v Cinobani (napr. Furmánek/Marková 1994, 388, 392; Furmánek/Sankot 1985, 276; Miroššayovál Javorský 1986, 664; Pieta 2008, 21, 37; Točík/Paulík 1979, 94, 98).

\section{CIEL, METODIKA, MOTIVÁCIA}

Cielom príspevku je nielen zrekapitulovat' už zverejnené predmety a upresnit ich nálezové situácie (Furmánek/Mitáš 2011a; 2014; Mitáš/Furmánek $2015 a, 161 ; 2015 b, 171-175)$, ale aj prezentovat dosial' bližšie nepublikované nálezy, ktoré svedčia o aktivitách Keltov na žiarových pohrebiskách z doby popolnicových polí v Cinobani a Radzovciach na juhu stredného Slovenska, a taktiež poukázat’ na dalšie laténske artefakty na obdobne datovaných pohrebiskách na Slovensku. Okrem toho sa zameriavame

\footnotetext{
1 Táto práca bola podporovaná Agentúrou na podporu výskumu a vývoja na základe Zmluvy č. APVV-16-0441 a projektom č. 2-0062-21 VEGA.
} 


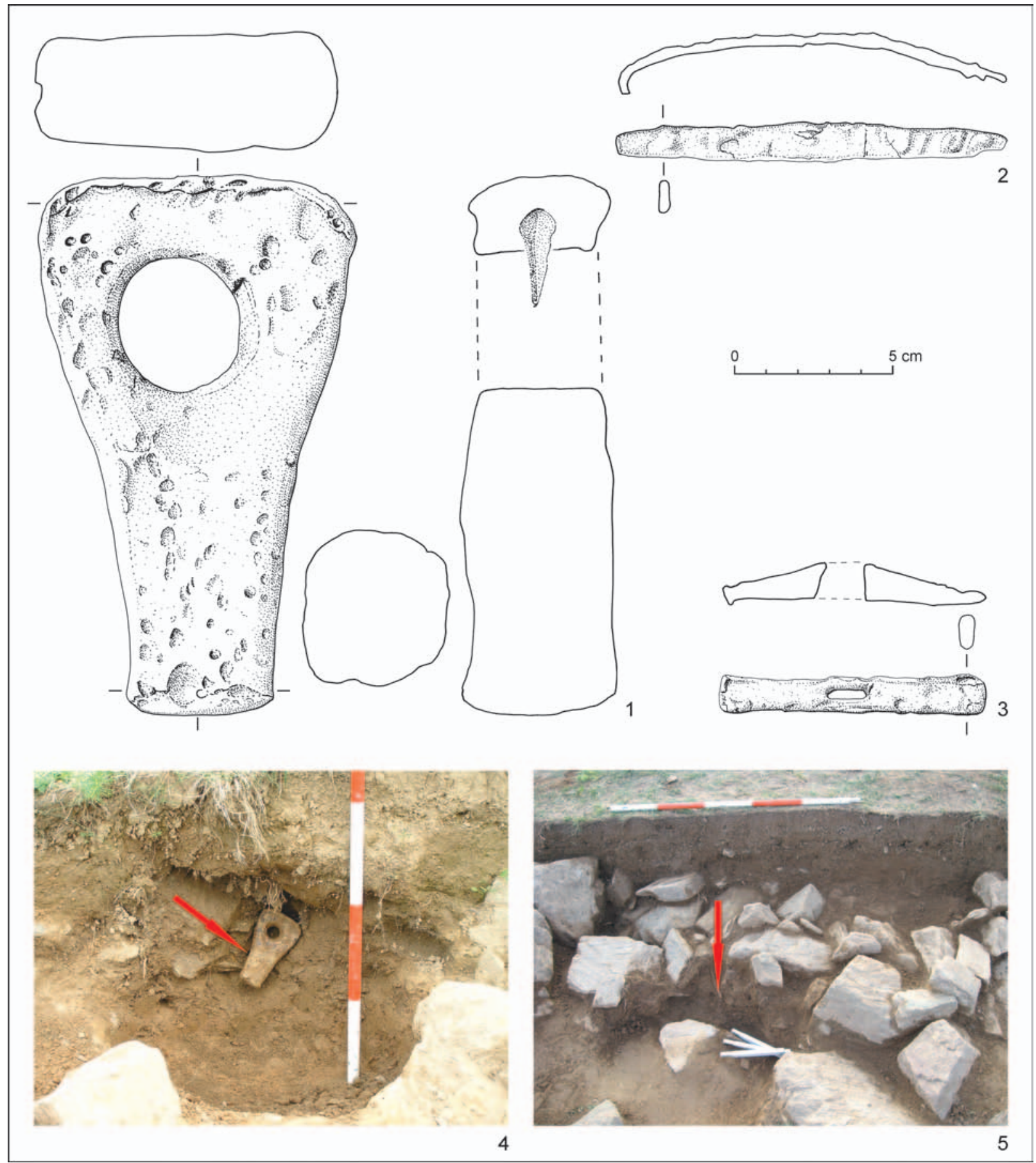

Obr. 1. Cinobaňa, poloha Jarčanisko. 1-3 - depot (čast’ depotu?) železných predmetov z doby laténskej zo žiarového pohrebiska; 4, 5 - nálezové situácie predmetov z depotu (upravené podl’a Furmánek/Mitáš 2014).

na ojedinelé či sporadické nálezy z doby laténskej na výšinných polohách a hradiskách, datovaných do mladších stupňov doby bronzovej a prípadne do staršej doby železnej. Vybrané náleziská a nálezy, ktoré dokumentujú aktivity Keltov, neuvádzame formou katalógu, ale venujeme im pozornost' $\mathrm{v}$ texte. Domnievame sa totiž, že táto forma je nateraz dostatočná a po zverejnení štúdie sa ich počet ešte rozšíri. Ďalej uvažujeme, že (možno) nie všetky "ojedinelé nálezy“ z doby laténskej realizátori výskumov pohrebísk a hradísk z doby popolnicových polí publikovali. Podotýkame, že niektoré z analyzovaných nálezov (napr. laténsku keramiku z kenotafickej mohyly v Cápore; Točík/Paulík 1979, 98) nemožno nájst’ ani v súpisoch klasických typov lokalít z doby laténskej (Březinová 2006, 29-42; Repka 


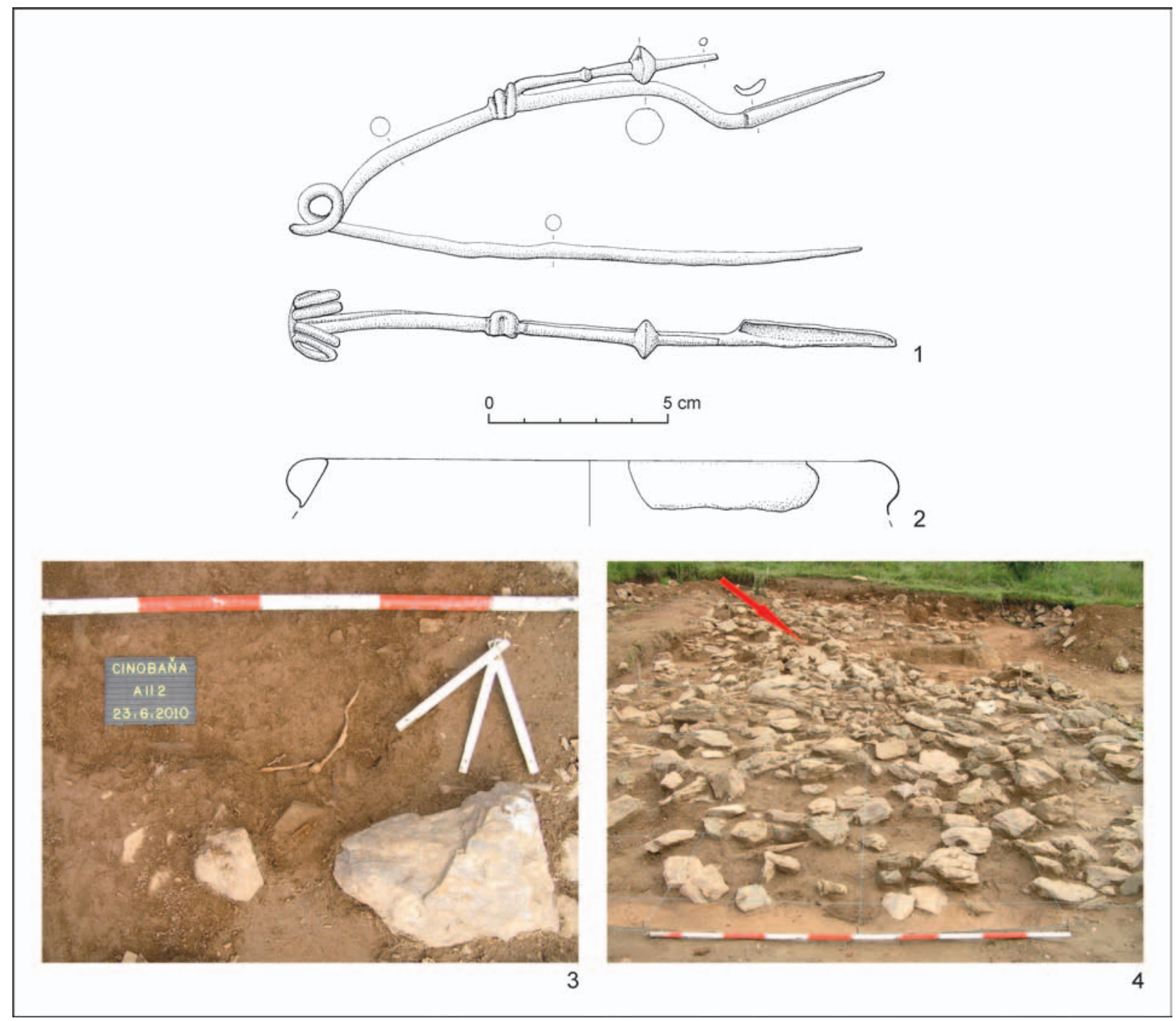

Obr. 2. Cinobaňa, poloha Jarčanisko. 1,2 - charakteristické artefakty z doby laténskej zo žiarového pohrebiska (upravené podla Furmánek/Mitáš 2014); 3 - nálezová situácia železnej spony; 4 - miesto nálezu spony na ploche pohrebiska.

2014, tabela 1). Stopy aktivít Keltov sa prehliadajú i z dôvodu, že vo viacerých prípadoch ich dokumentujú (alebo môžu dokumentovat') práve málo výrazné ojedinelé nálezy (napr. zlomky keramiky a železných predmetov). $V$ príspevku zohladňujeme nálezy zverejnené vo vedeckej spisbe a hlavne bud' plošne dostatočne preskúmané, alebo viacnásobne rekognoskované archeologické lokality, eventuálne náleziská, ktoré poznáme z autopsie. Pochopitelne, že niektoré nálezy (napr. železný nôž z Marianky; Paulík 1996) dávame do pozornosti aj preto, aby sa o nich diskutovalo. Analyzovaný materiál porovnávame s analogickými dokladmi prítomnosti laténskej kultúry na pohrebiskách, výšinných polohách a hradiskách z doby popolnicových polí až z doby halštatskej v okolitých krajinách. Motivovali nás najmä výsledky výskumu tohto fenoménu v Českej republike v druhej polovici 20. stor. a zvlášt v ostat- ných rokoch na výnimočnej lokalite Rovná v južných Čechách (Chytráček a i. 2017a; 2017b). Pozorovaním výskumu v zahraničí v princípe legitimizujeme náš pohl’ad na aktivity Keltov na území Slovenska. Súčastou vyhodnotenia je pokus o kategorizáciu a interpretáciu pertraktovaných nálezov.

\section{KELTI A POHREBISKÁ Z DOBY POPOLNICOVÝCH POLÍ NA JUHU STREDNÉHO SLOVENSKA \\ K nálezom z doby laténskej v Cinobani}

Signifikantné doklady aktivít Keltov sa zdokumentovali na žiarovom pohrebisku v k. ú. obce Cinobaňa (okr. Poltár). Terénny výskum pohrebiska v polohe Jarčanisko sa realizoval v rokoch 

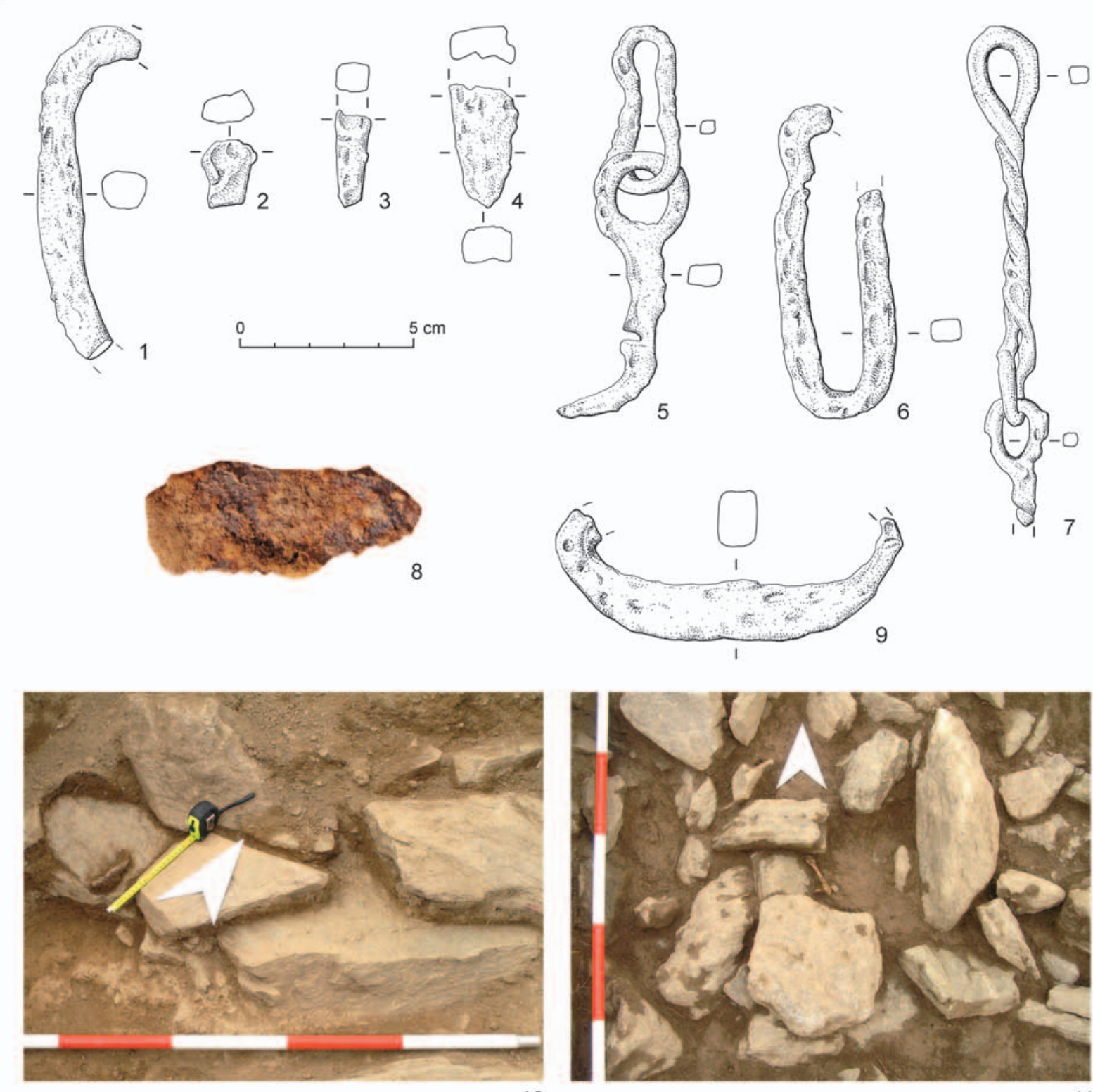

10

11
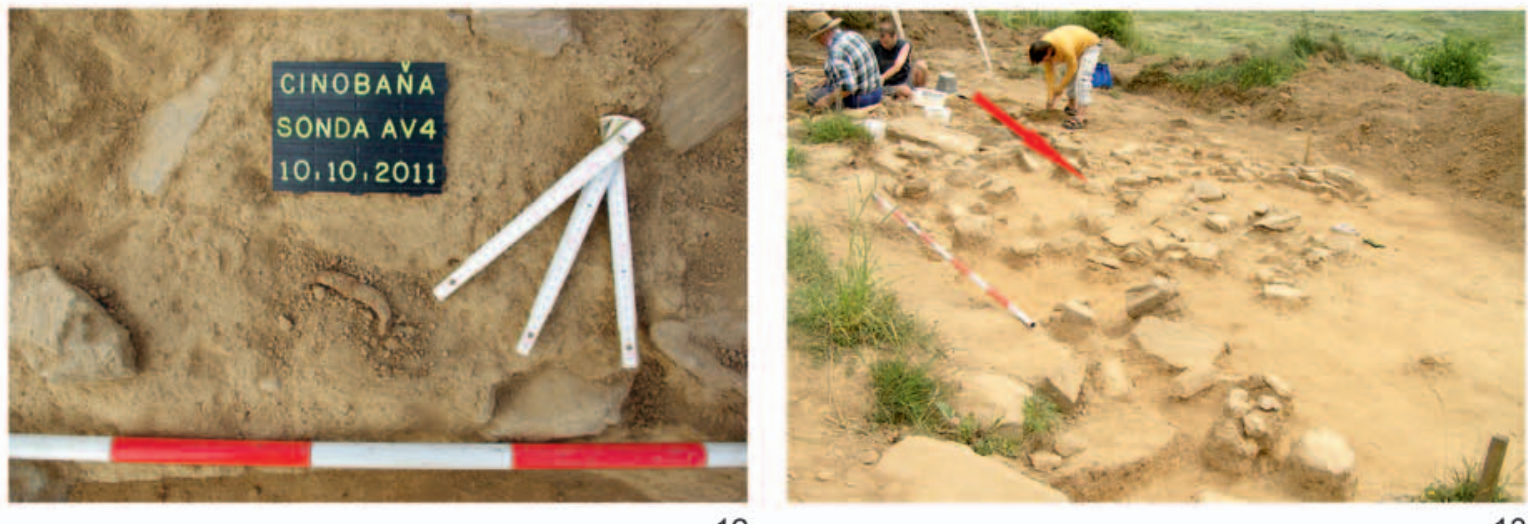

12

Obr. 3. Cinobaňa, poloha Jarčanisko. 1-9 - výber železných predmetov z doby laténskej zo žiarového pohrebiska, nálezy z výskumných sezón 2008-2011 (upravené podl’a Furmánek/Mitáš 2014); 10-13 - nálezové situácie vybraných železných artefaktov. Mierka: 1-7, 9; bez mierky -8 . 
2007-2014. Na ploche 7 árov sa systematicky preskúmalo celkom 314 hrobov pilinskej a kyjatickej kultúry z mladšej až neskorej doby bronzovej (Furmánek/Mitáš 2019). Vzhladom na výsledok geofyzikálneho merania je evidentné (Cheben 2015, 123, obr. 12), že ide asi o polovicu z celkovej plochy pohrebiska. Pohrebisko je situované na svahu horskej lúky, ktorá sa dlhodobo využíva ako pastvina a nikdy sa neorala. Charakteristické je deštrukciami kamenných hrobových úprav a konštrukcií, medzi ktorými vynikajú klasické kamenné skrinky s vencami z mladšej doby bronzovej, a kameňmi naznačené skrinky pod príkrovmi z neskorej doby bronzovej.

Železné artefakty, a to aj celkovo reprezentatívne (obr. 1: 1-3), sa objavili na ploche pohrebiska už v roku 2008 (Furmánek/Mitáš 2010a, obr. 15). Avšak v rámci prospekcie súvekého sídliska v polohe Krivé zeme (tiež Jarčanisko II), ktoré je od pohrebiska vzdialené asi 400-500 m na juh až juhovýchod, sa $\mathrm{v}$ tomto roku našla iba keramika $\mathrm{z}$ mladšej a neskorej doby bronzovej, poprípade stopy aktivít z novoveku. Charakteristickú keramiku z doby laténskej a vel'ké kusy železnej trosky doložili až opakované prieskumy na sídlisku v roku 2009 (Furmánek/Mitáš 2013, 101; Mitáš/Furmánek 2015b, 186). Sídliskové nálezy zo zberu, ale aj detailnejšie štúdium železnej industrie (po jej laboratórnom očistení a zakonzervovaní), ktorá sa zhromaždila na ploche pohrebiska v rokoch 2008 a 2009, vzápätí vzbudili pochybnosti o jej predbežnom datovaní do záveru kyjatickej kultúry, resp. prelomu stupňov HB a HC. Prítomnost' materiálnej kultúry Keltov na žiarovom pohrebisku v Cinobani sa definitívne potvrdila $\mathrm{v}$ roku 2010 typickými laténskymi nálezmi (Mitáš/Furmánek 2015a, 161, obr. 82: 1, 2): železnou sponou spojenej konštrukcie (obr. 2: 1) a zlomkom z okraja keramickej nádoby (obr. 2: 2). Možno doplnit', že spona sa objavila pri začistovaní kameňov deštruovaných hrobových architektúr (obr. 2: 4), približne na hornej úrovni podložia. Ihla tejto dlhej železnej spony bola v okamihu objavenia výrazne roztvorená a pätka odlomená (obr. 2: 3). Laténsky keramický fragment sa vyskytol v tej istej úrovni, severozápadne od spony. Dalšie železné predmety boli nájdené na pohrebisku v rámci výskumných sezón 2011 a 2012 (obr. 3: 5, 6, 9). Viaceré zlomky ležali medzi kameňmi na južnom okraji pohrebiska (obr. 3: 12, 13). Iné artefakty pochádzajú zo zatrávnenej plochy južne od okraja pohrebiska, resp. z miest, na ktorých sa $\mathrm{v}$ dobe bronzovej už určite nepochovávalo. Tieto železné predmety boli pomerne plytko $\mathrm{v}$ zemi a zistili sa prieskumom detektorom kovov.

\section{Od železného prútu z Cinobane k d’alším artefaktom}

Prvým železným artefaktom, ktorý sa objavil na žiarovom pohrebisku v roku 2008, bol fragment ohnutého masívneho prútu (obr. 3: 1). Ležal medzi kameňmi príkrovu, ktorý zakrýval naznačenú skrinku hrobu 4/08 (obr. 3: 10). Početné železné zlomky sa našli v kamennej konštrukcii hrobu 6/08 a v jeho blízkom okolí (obr. 3: 11). Niektoré z nich sú funkčne tažko určitelné (obr. 3: 2-4). Jeden železný predmet sme v rámci prvej výskumnej sezóny (2008) klasifikovali ako zubadlo z uzdy, ktoré by mohlo mat' súvis s včasnohalštatskými nálezmi východokarpatského typu (Kemenczei 2005, 108). Zakrátko sme ale zistili, že ide o článok retaze z doby laténskej (obr. 3: 7; Furmánek/Mitáš 2011a, 117, 119, 121, obr. 3: 9; 2014, 99, 101, obr. 3: 5). Tvarovo typické železné predmety sa objavili medzi kameňmi západne od kamenného venca skrinkového hrobu 6/08 (obr. 1:4, 5). Bolo to masívne kladivo (obr. 1: 1), malé kladivo (obr. 1: 3) a kramla (obr. 1: 2). Kladivo a kladivko sme našli tesne vedla seba, kramlu blízko nich. Z ich uloženia bolo zjavné, že ide o depot. Zlomky železných predmetov sa zistili aj okolo kamenných konštrukcií hrobov 48/08 a 55/08 (obr. 12). Všetky

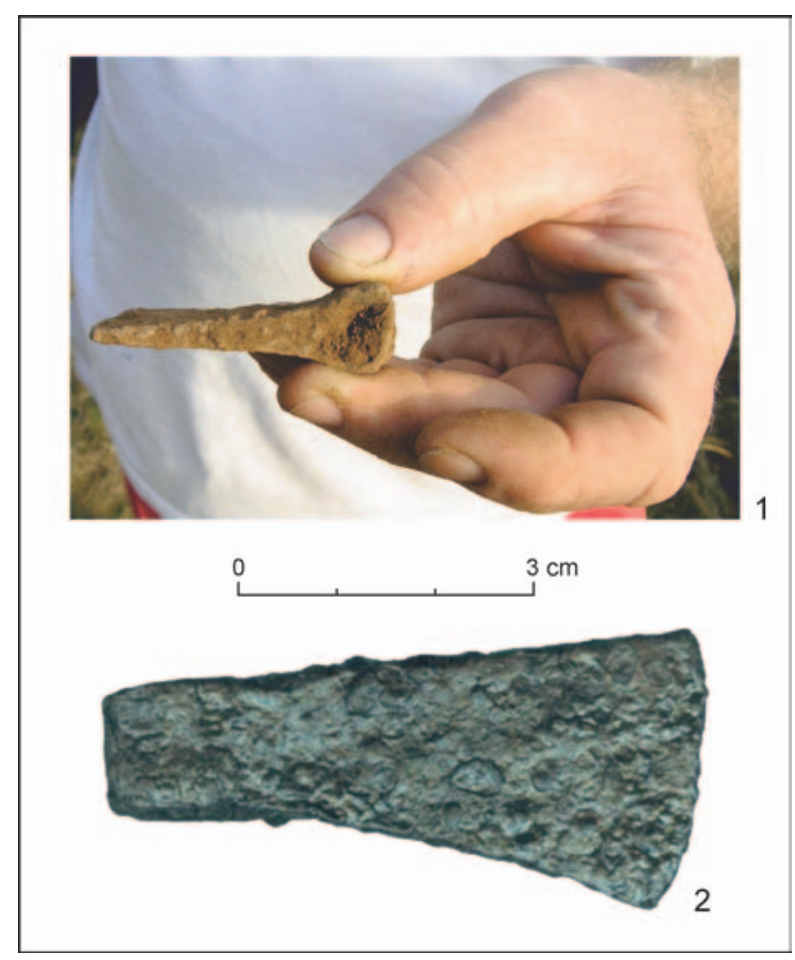

Obr. 4. Cinobaňa, poloha Jarčanisko. Miniatúrna železná sekera. 1 - stav predmetu po objavení; 2 - stav predmetu po konzervácii (podla Furmánek/Mitáš 2010a). 


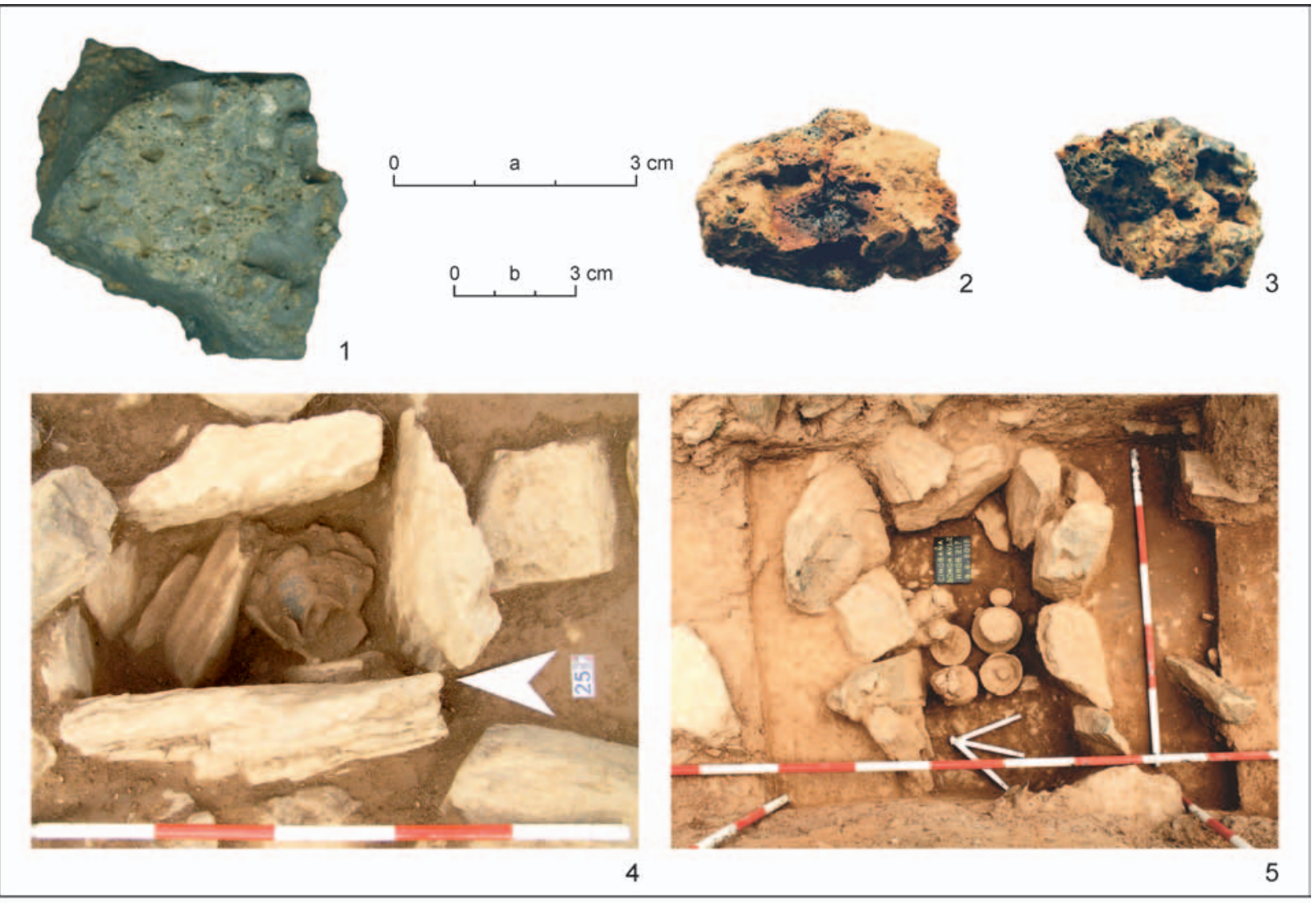

Obr. 5. Cinobaňa, poloha Jarčanisko. 1-3 - železná lupa a troska zo žiarového pohrebiska (upravené podla Furmánek/ Mitáš 2010a; 2011a); 4, 5 - hroby 25/08 a 217/11(12). Mierka: a - 1; b-2, 3.

uvedené nálezy síce mohli byt’ súčastou hrobov, avšak nenašli sa priamo $\mathrm{v}$ skrinke, vo vnútri keramickej urny alebo $\mathrm{v}$ niektorej z príloh. $\mathrm{V}$ rade železných predmetov, ktoré sme v roku 2008 na ploche pohrebiska zaevidovali, stojí za pozornost' aj miniatúrna sekera (obr. 4). Zachytila sa detektorom kovov východne od otvorených sond, na doteraz nepreskúmanej časti pohrebiska, z ktorej sa pred geofyzikálnym meraním plánovali odstránit náletové dreviny. Pozoruhodná nálezová situácia sa naskytla v prípade železnej lupy (obr. 5: 1), ktorá ležala na miske obrátenej hore dnom. Táto miska zakrývala urnu v skrinkovom hrobe 25/08 z mladšej doby bronzovej (obr. 5: 4). Skrinku hrobu 25/08 prekrývali kamene, ktoré pôvodne tvorili malý mohylový násyp. Ani kamenná architektúra hrobu ani vnútro kamennej skrinky nevykazovali znaky narušenia, čo sme už zdôraznili (Mitáš/Furmánek 2015b, 174). Podobne skrinkový hrob 217/11(12) z neskorej doby bronzovej, nad ktorým sa našli kusy železnej trosky (obr. 5: 2, 3), nejavil žiadne stopy sekundárneho zásahu (obr. 5: 5). To však nemožno skonštatovat' o skrinkových hroboch 62/09 (obr. 6: 1, 2), 66/09 (obr. 6: 3, 4) a 160/10 (obr. 6: 5, 6), ktoré boli v minulosti intencionálne otvorené a hrobový inventár viditel'ne narušený. Zásahy vo všetkých prípadoch dosiahli až dná týchto skriniek. Už pri exkavácii prvého hrobu z tejto kategórie bolo evidentné, že kamenné kvádre zo skrinkovej konštrukcie niekto pred nami odvalil, premiestnil a položil ich bokom, pričom vnútro skrinky nápadne porušil (obr. 6: 1, 2). $\mathrm{V}$ rámci tejto aktivity sa evidentne manipulovalo aj s keramickou urnou, resp. so spálenými kostami. Tie sa v hrobe 62/09 nenašli vôbec. Výskumom dalších skrinkových hrobov sa tieto terénne pozorovania zopakovali a naše úvahy o aktivitách Keltov na pohrebisku utvrdili.

$S$ ohladom na vyššie uvedené skutočnosti sa do nového svetla dostávajú aj iné železné predmety zo žiarových pohrebísk na juhu stredného Slovenska. $\mathrm{V}$ prvom rade to je masívny železný nôž s rukovätou, ktorej koniec bol vykovaný do tvaru eliptického oka (obr. 7: 1). Tento sa objavil na žiarovom pohrebisku pilinskej a kyjatickej kultúry v Radzovciach (okr. Lučenec). Pôvodne sa dával do súvisu s inventárom hrobu 729/73 (obr. 7: 2). Datovali sme ho do neskorej doby bronzovej a do záverečného horizontu pochovávania na pohrebisku, t. j. horizontu Radzovce V (Furmánek/Mitáš 2010b, 100, 101). Nad skrinkovou konštrukciou citovaného hrobu kyjatic- 

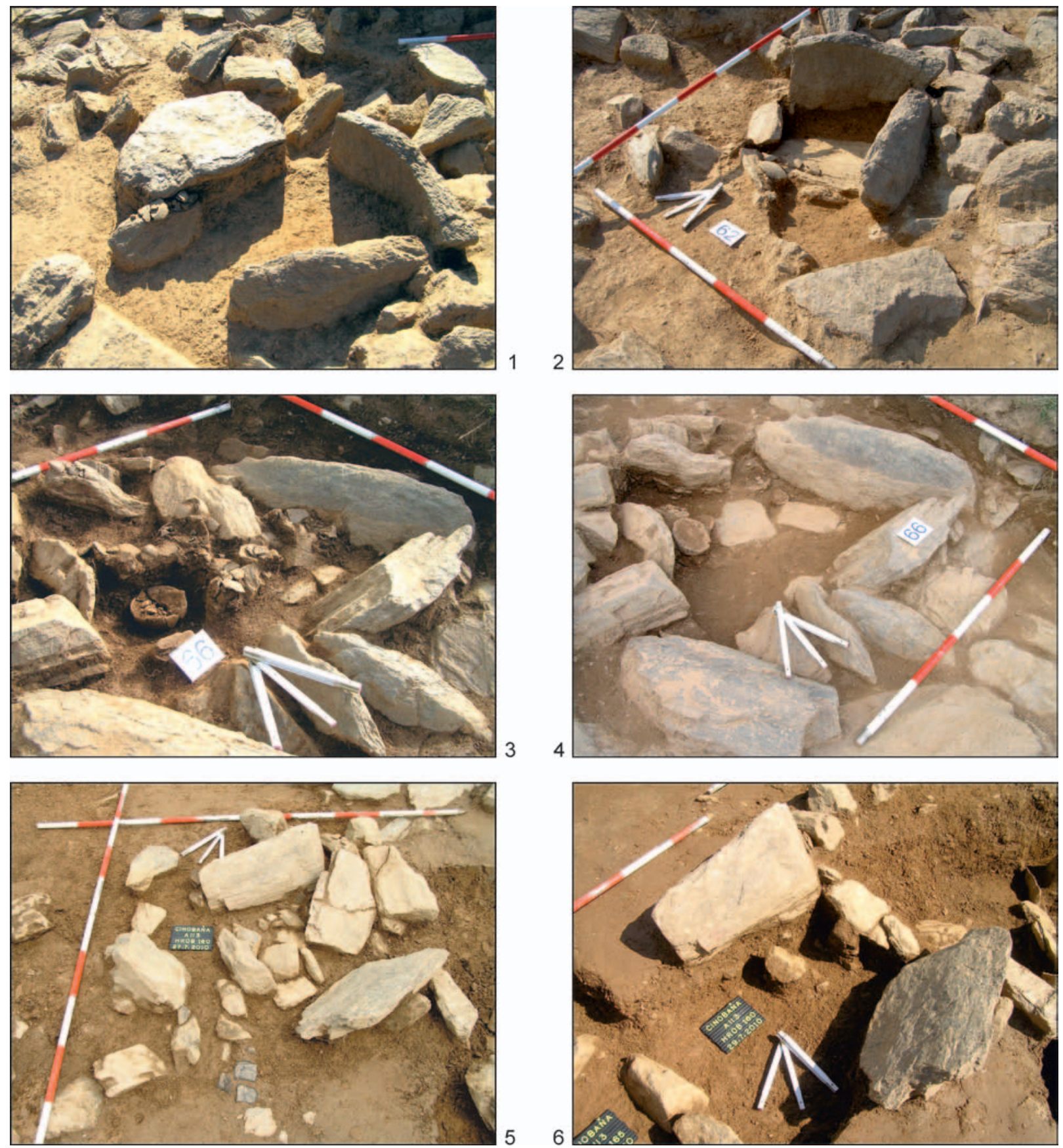

Obr. 6. Cinobaňa, poloha Jarčanisko. 1-6 - hroby kyjatickej kultúry s narušenými skrinkami a inventárom (upravené podla Furmánek/Mitáš 2011a).

kej kultúry bol vel'ký kamenný príkrov. Dno hrobu sa nachádzalo v hlbke $225 \mathrm{~cm}$. Masívny železný nôž ležal medzi kameňmi v hornej časti príkrovu v híbke 215 cm (Furmánek/Mitáš/Budaváry 2016, 261, 262, tab. C: 16). K híbkam nameraným v roku 1973 však treba dodat, že sú výsledkom postdepozičných procesov na svahu so žiarovými hrobmi a určite nezodpovedajú stavu lokality v dobe laténskej. Iné materiálne doklady aktivít Keltov sa na pohrebisku a sídlisku z doby popolnicových polí v Radzovciach neobjavili (Furmánek 1990; 2010; 2019). Najbližšie sídlisko z doby laténskej v povodí Belinského potoka, od pohrebiska pilinskej a kyjatickej kultúry na polohe Monosa v Radzovciach vzdialené ani nie $4 \mathrm{~km}$, sa doložilo na severe katastra obce Radzovce povrchovým zberom (Furmánek/Sankot 1985, 275). Neobyčajné stopy keltského osídlenia sa evidujú aj na impozantnej výšinnej opevnenej polohe 


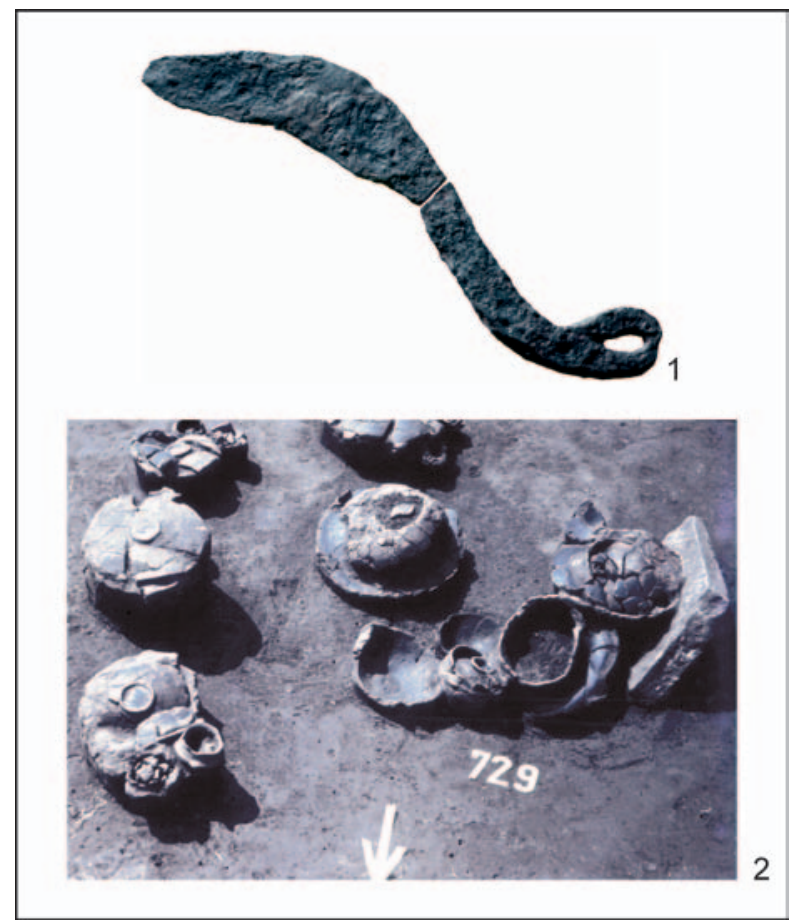

Obr. 7. Radzovce, poloha Monosa. 1 - unikátny železný nôž z kamenného príkrovu hrobu 729/73 (podla Furmánek 2010); 2 - hrob 729/73 kyjatickej kultúry (podla Furmánek/ Mitáś/Budaváry 2016).

Pohanský hrad (tiež Pogány vár). Väčšia čast’ tejto archeologickej lokality s najvyšším bodom $578 \mathrm{~m}$ patrí do k. ú. obce Stará Bašta, okr. Rimavská Sobota (Furmánek 1996, 126, 128, 129), a od sídliska z doby popolnicových polí v Radzovciach je vzdušnou čiarou vzdialená necelých $5 \mathrm{~km}$.

S istou dávkou skepticizmu v súčasnosti nazeráme aj na datovanie torza železného noža z revízneho výskumu v obci Babinec (okr. Rimavská Sobota). Tento predmet sa našiel na povrchu pohrebiska kyjatickej kultúry, ktoré bezo zvyšku preskúmal na konci 19. stor. amatérsky archeológ István Terray. Jednoduchý železný nôž z Babinca nie je typologic$\mathrm{ky}$, ale ani chronologicky smerodajným artefaktom. Napriek tomu sa mu pripísal súvis so železiarstvom kyjatickej kultúry v neskorej dobe bronzovej (Furmánek 1984, 77; 1988, 188, obr. 4). Pravdepodobne však ide o predmet $\mathrm{z}$ doby laténskej (pozri a porovnaj so súvekými železnými kuchynskými nožmi napr. Pieta 2008, 149, obr. 69: 12, 13) a doklad aktivity Keltov na pravekom žiarovom pohrebisku s dobre viditelnými mohylovými násypmi.

Osobitým prípadom je lokalita Vyšná Pokoradz, okr. Rimavská Sobota (v súčasnosti čast’ mesta Rimavská Sobota). Amatérske vykopávky realizované už od prvej polovice 19. stor. v polohe Háj ukázali, že ide o jednu z významných lokalít juhovýchodných popolnicových polí, dokumentovanú sídliskom, žiarovým pohrebiskom a hromadnými nálezmi bronzových predmetov z mladšej a neskorej doby bronzovej. Na lokalite pilinskej a kyjatickej kultúry sa objavili aj doklady laténskej materiálnej kultúry a nechýbajú ani keltské mince (Furmánek 1985, 174; Furmánek/Sankot 1985, 275). Vzájomné vztahy pravekých objektov a laténskych nálezov (intencionálne zásahy, či intrúzie v rámci polykultúrnej lokality) sú však s odstupom času neurčitel'né. Žial', problematický je tiež vzájomný vzţah hrobových nálezov na halštatskom a laténskom pohrebisku Drňa, okr. Rimavská Sobota (Furmánek 1975, 49; Furmánek/ Sankot 1985, 276, 277).

\section{Poznámky k datovaniu vybraných nálezov zo železa}

Nezanedbatelnou súčastou sledovanej problematiky je otázka chronologickej pozície vyššie spomenutých železných predmetov, alebo aspoň tých, ktoré sú tvarovo typické. K datovaniu aktivít Keltov na pohrebisku v Cinobani sú zásadnými artefaktmi vel'ká spona spojenej konštrukcie (obr. 2: 1), masívne kováčske kladivo (obr. 1: 1), prípadne článok retaze (obr. 3: 7).

Najbližšie analógie k železnej spone spojenej konštrukcie nachádzame na laténskych pohrebiskách na juhu stredného Slovenska (Drňa, okr. Rimavská Sobota; Furmánek/Sankot 1985, 290, obr. 12: 2) a v prilahlej oblasti severného Mad’arska (Ludas, obvod Gyöngyös; Szabó/Tankó 2012, 23, 24, 69, 70, tab. VII: 1, 2; XLII: 2, 3). Spona z hrobu 5/74 v Drni je dlhá $176 \mathrm{~mm}$, dvojice spôn v hroboch 665 a 1056 z Ludasu 116, 120 a 128, 124 mm. Poškodený cinobanský exemplár má dížku 170 mm (obr. 2: 1), teda takmer totožnú so sponou z Drne. Citované hrobové nálezy tohto typu železnej spony sú zhodne datované do stupňa LTC1 (Furmánek/Sankot 1985, 292; Szabó/Tankó 2012, 142, 144, 145, obr. 186; 187). Zaiste nie je nezaujímavé, že výskyt dlhej spony na zopnutie plášta z hrubej látky sa v Karpatskej kotline všeobecne viaže na bojovnícke hroby (Furmánek) Sankot 1985, 292), avšak poznáme aj ojedinelé nálezy z výšinných polôh (Slovenské Pravno-Sokolia skala; Pieta 2008, obr. 2: 16).

Masívne železné kladivá s vel'kým otvorom na porisko a spravidla aj so stopami po používaní patria k charakteristickému náradiu na opracovanie kovov z doby laténskej (Pieta 2008, 145, 147, obr. 64: 3, 7; 67: 1, 2) nielen na území Slovenska (napr. na Morave - Čižmáŕ 1996, obr. 9: 1; v Čechách - Venclová 2008, obr. 36: 6, 7, príloha 5: 2; v Rakúsku - Gruber 2015, 80-82, obr. 11; ale i v Madarsku - Almássy 2005, 99, 106, obr. 1; autori príspevku tieto typy kladív poznajú z autopsie aj zo severovýchodného Ma- 
d’arska, z Aggteleckého krasu). Nálezy tohto typu $\mathrm{v}$ depotoch železných nástrojov napr. $\mathrm{z}$ Plaveckého Podhradia-Pohanskej (Čambal 2009, 155, tab. I: 6, obr. 2: 4; Pieta 2008, 147, obr. 67: 1, 2) sú datované na koniec strednej doby laténskej, t. j. do stupňa LTC2 (Čambal 2009, 161, 162; Pieta 2008, 147), avšak registrujeme ich aj v železných depotoch z neskorej doby laténskej (napr. Bezdědovice, južné Čechy; Michálek 1999, 8, 38, 45-47, obr. 6: 601, 602; 16: 601, 602; 19; 20: 1, 2).

Článok železnej retaze s obojstrannými okami (obr. 3: 7) sa podobá na zverejnené súčasti závesných retazí na kotol (Pieta 2008, 229, obr. 111: 8), poprípade na segmenty retazového opaska na meč (Čambal 2009, 158, tab. III: 1a, 1b), ktoré poznáme aj zo Slovenska (s ohladom na sledovaný geografický rámec pozri tiež materiál z mad’arského keltského pohrebiska Ludas; Szabó/Tankó 2012, 111-113, 141-149; analógie z okolitých krajín vzhladom na fragmentárne zachovalú retaz neuvádzame, hoci ich registrujeme). Nález z Cinobane v kontexte s ostatnými železnými predmetmi z plochy žiarového pohrebiska rámcovo datujeme do strednej až neskorej doby laténskej.

K vyššie opísanej železnej sekerke z Cinobane (obr. 4), aj ked' ju nepovažujeme za chronologicky citlivý artefakt poznamenávame, že obdobné drobné predmety predstavovali v keltsko-rímskom svete votívne dary (Kiernan 2009, 1-10). Sekerky patrili $\mathrm{k}$ všeobecne najrozšírenejším a mohli byt' aj amuletmi (Kiernan 2009, 114; Kysela/Venclová 2018, 137; Pieta 2008, 300-304). K nášmu nálezu tvarovo blízka miniatúrna sekera, avšak v bronzovom vyhotovení, pochádza aj z eponymnej lokality laténskej kultúry (Kiernan 2009, 255, 256: SU18). Zmienka o votívnych predmetoch na tomto mieste nie je samoúčelná $\mathrm{a} \mathrm{v}$ rámci vyhodnotenia sa $\mathrm{k}$ tejto problematike ešte vrátime. Žiada sa ešte podotknút, že amuletmi v dobe laténskej bývali aj napr. neolitické kamenné sekerky s prevŕtaným otvorom na zavesenie (napr. z mad’arského pohrebiska Vác, poloha Piesková jama, obvod Vác; Hellebrandt 1999, 55, 60, 91, tab. XXVI: 12), čo tiež svedčí o záujme Keltov o staršie artefakty. Prípadov tohto typu je z keltského prostredia viac (John a i. 2015a, 13, obr. 8: 1).

Tvarovo typický železný nôž, priložený ku kamennému príkrovu vyššie citovaného hrobu kyjatickej kultúry v Radzovciach, patrí do skupiny kosákovitých zberových nožov (Pieta 2008, 222, 224, obr. 108). Železné nože s kosákovitou čepelou a pevnou rukovätou ukončenou krúžkom sa na juhu stredného Slovenska objavujú v strednej dobe laténskej (Včelince, okr. Rimavská Sobota; Pieta 2008, 222, obr. 108: 1) a v horskom prostredí na strednom Slovensku v predpúchovskom stupni (Horná Lehota, okr. Brezno; Pieta 2008, 222, obr.
108: 17). Najčastejšie sa nože tohto typu vyskytujú na neskorolaténskych sídliskách púchovskej kultúry a nechýbajú ani na niektorých keltských lokalitách západného Slovenska (Trenčianske Bohuslavice, okr. Nové Mesto nad Váhom; Pieta 2008, 222, obr. 108: 11, 12). Jednoznačnú analógiu k železnému nožu z Radzoviec však nepoznáme.

\section{AKTIVITY KELTOV NA POHREBISKÁCH LUŽICKÝCH A STREDODUNAJSKÝCH POPOLNICOVÝCH POLÍ}

Jedným z najsignifikantnejších dokladov keltskej aktivity na pravekom objekte z územia Slovenska je nález náramku z modrého skla na mohylovom pohrebisku lužickej kultúry v obci Krásna Ves, okr. Bánovce nad Bebravou. Uvedený sklený náramok (obr. 8: 13) ležal na okraji mohylového násypu hrobu 22 z mladšej doby bronzovej, ktorý bol v centrálnej časti viditelne porušený (Budinský-Krička/Veliačik 1986, 43-46, obr. 22). V kamennej konštrukcii tohto hrobu sa našla aj dvojčepel'ová bronzová britva z mladšej doby bronzovej (Budinský-Krička/Veliačik 1986, 43-45, obr. 21, tab. IX: 35) a d’alšie praveké artefakty. Laténsky sklený náramok s obdobnými nálezovými okolnostami, eventuálne $\mathrm{z}$ objektu tohto typu z doby popolnicových polí, nie je na Slovensku známy (Březinová 2018, 30). Pozoruhodné nálezy púchovskej kultúry, hoci bez bližšej stratigrafickej informácie, dalej pochádzajú z mohylového pohrebiska lužickej kultúry z mladšej doby bronzovej v Sklabinskom Podzámku, okr. Martin. Ide o artefakty z neskorej doby laténskej: bronzovú sponu typu Almgren 18 (obr. 8: 2) a keramické zlomky z hrnca zdobeného typickým ryhovaním (obr. 8: 3, 4; Horñák 2005, 210, 211, tab. IV: 3, 5, 8). Zaiste nie je náhodné, že bronzová spona sa objavila pri odkrývaní jedného z kamenných vencov na pohrebisku (Horñák 2005, 210). Ako už bolo poznamenané (Horñák 2005, 211), v tomto prípade môžu mat laténske nálezy súvis s blízkym a vzdušnou čiarou asi 500 m vzdialeným súdobým sídliskom púchovskej kultúry, ktoré sa rozprestiera na poliach pri Sklabinskom hrade, a teda aj so starou komunikačnou trasou, ktorá viedla Turčianskou kotlinou. V katastri Sklabinského Podzámku však Keltov zaujali aj podstatne vyššie polohy, o čom svedčia sporadické laténske nálezy (obr. 8: 5, 6) z tažko dostupného hradiska lužickej kultúry z neskorej doby bronzovej a počiatku staršej doby železnej na Katovej skale v nadmorskej výške 927 m (Pieta 2008, obr. 2: 15; Veliačik/Kujouský/Romsauer 2008, 172). Výnimočným kovovým artefaktom z Katovej skaly je krabicovitá pásová zápona z včasnej doby laténskej (obr. 8: 5; Pieta 2008, 18, 21, obr. 2: 7; Pieta/Veliačik 2014, 8, 


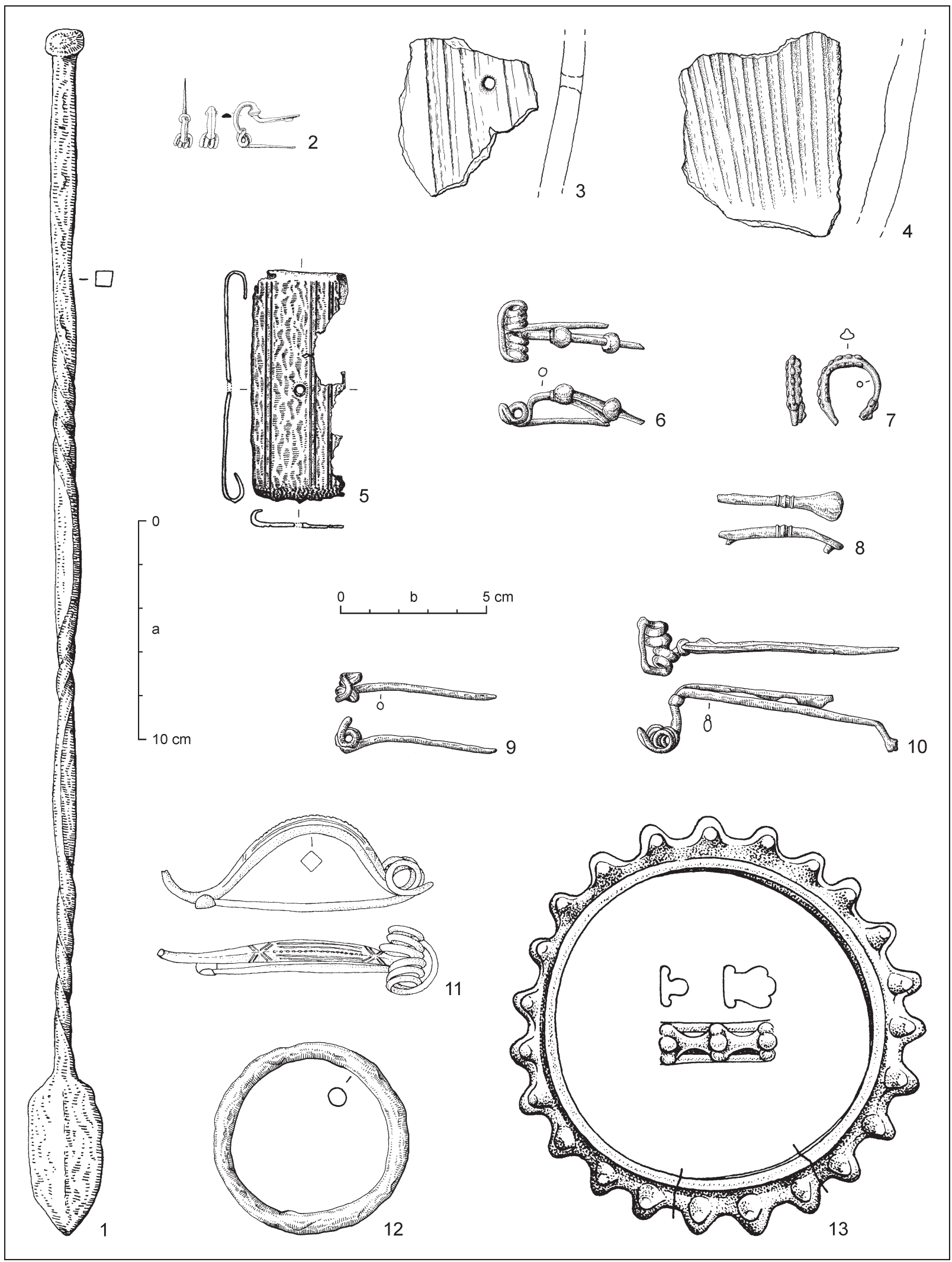

Obr. 8. Materiál dokumentujúci keltské aktivity na lokalitách z doby popolnicových polí na Slovensku. 1 - Palárikovo II; 2-4 - Sklabinský Podzámok, poloha „ústie Kantorskej doliny“; 5, 6 - Sklabinský Podzámok, poloha Katova skala; 7, 8 - Rybník, poloha Krivín; 9, 10, 12 - Málinec, poloha Zámok; 11 - Vítkovce, poloha Tureň; 13 - Krásna Ves, poloha Pieskovisko. 1, 5-10, 12 podla Pieta 2008; 2-4 podla Horňák 2005; 11 podl’a MiroššayoválJavorský 1986; 13 podl’a Budinský-Krička/Veliačik 1986. Mierka: a - 1; b-2-12; bez mierky - 13. 

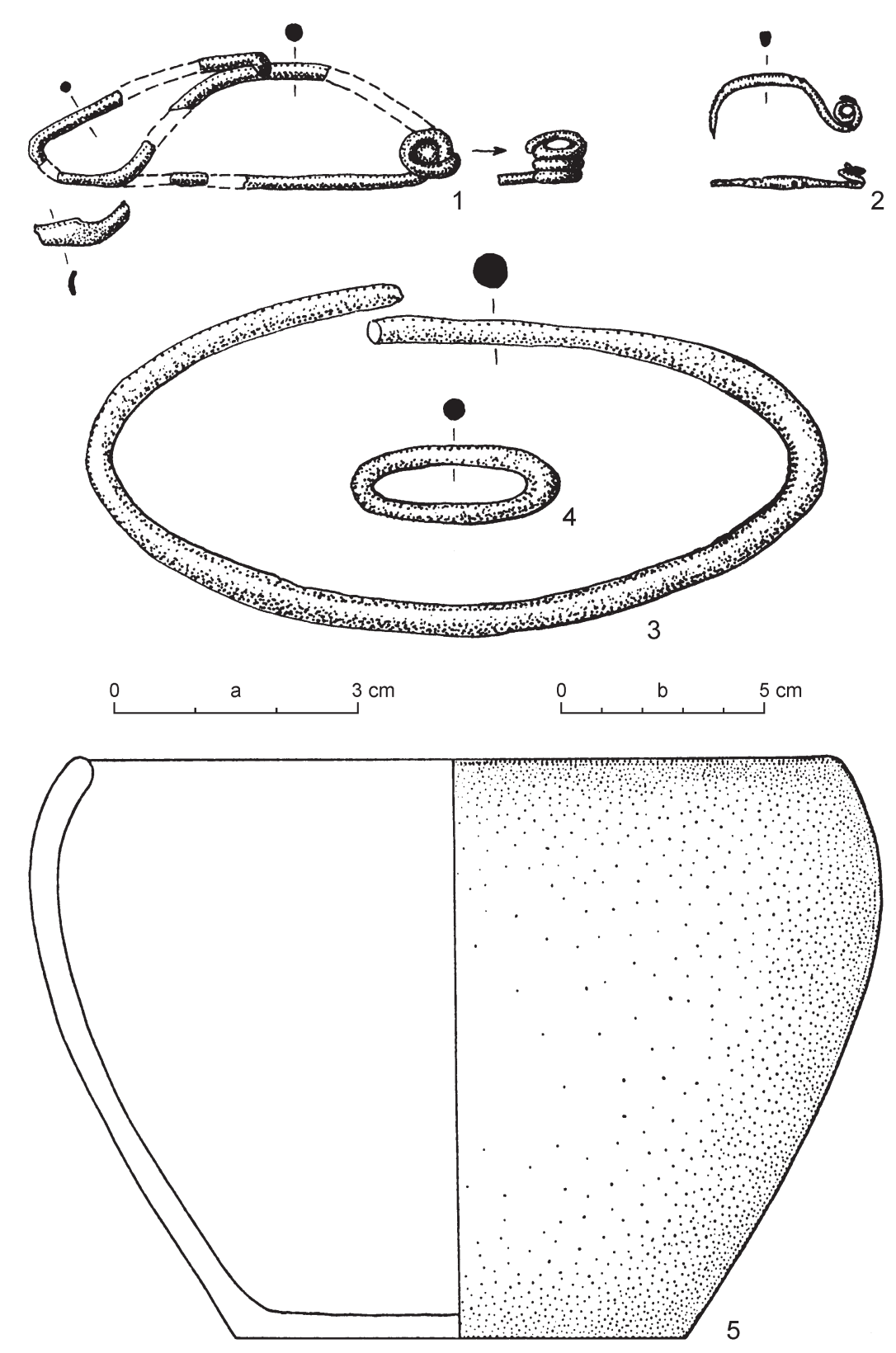

Obr. 9. Včelince, poloha Halomszer. Inventár hrobu z doby laténskej z násypu pravekej mohyly (upravené podl’a Furmánek/Marková 1994). Mierka: a - 1-4; b-5.

obr. 3: 17). Na výskyt včasnolaténskych artefaktov tzv. solitérov poukazujú aj iné lokality v regiónoch na severe Slovenska (Pieta 1983, 46; 2008, obr. 2: 2).

Keltský materiál sa vyskytol tiež v mohylách kultúrneho komplexu stredodunajských popolnicových polí na západnom Slovensku. Do plášta mohyly čačianskej kultúry z mladšej doby bronzovej v Palárikove, okr. Nové Zámky, bolo v dobe laténskej uložených niekol'ko hrobov s pozoruhodným inventárom vrátane železnej vyhňovej lopatky (obr. 8: 1), ako aj zapustená etážovitá „,kultová jama“.
Citované objekty zo strednej doby laténskej pravdepodobne predstavovali osobitý „,kultový komplex“ (Paulík 1974; 1976a, 369; Paulík/Zachar 1975, 318). Situovanie keltského obetiska a pätice hrobov (podla realizátora výskumu Jozefa Paulíka a v súpisoch pohrebísk tiež Palárikovo II; Paulík/Zachar 1975, 284) na terénnej dominante $v$ močaristom teréne, severne od plochého pohrebiska z doby laténskej v polohe I (Repka 2014, 38), zrejme nie je náhodné. V súvislosti so sledovanou kategóriou nálezov upozorňujeme aj na zlomok z grafitovej keramiky 
hrncovitého tvaru z doby laténskej, ktorý sa našiel v splavenej okrajovej vrstve mohyly z mladšej doby bronzovej v obci Cabaj-Čápor (v časti Čápor), okr. Nitra (Točík/Paulík 1979, 87, 94, 98). Je zaujímavé, že výrazné terénne dominanty - mohyly z mladšej doby bronzovej (čačianskej kultúry) v Ćápore a Palárikove, $\mathrm{v}$ ktorých sa identifikovali kvalitatívne síce odlišné aktivity Keltov, sú interpretované ako kenotafické (Paulík 1976a, 369; Točík/Paulík 1979, 100, 102). Dva žiarové hroby z doby laténskej boli vyhíbené aj do násypu, ktorý údajne vykazoval všetky znaky mohyly, na lokalite Chotín V (poloha Sashegy), okr. Komárno. Tento násyp sa ale podla dostupných správ v 50.-60. rokoch 20. stor. detailnejšie neprebádal (Dušek 1961, 66).

Ukladanie hrobov do pravekých mohýl a prírodných mohylovitých útvarov $\mathrm{v}$ dobe laténskej je archeologicky doložené aj na juhu stredného Slovenska. Ojedinelý žiarový (urnový) hrob sa objavil v násype vel'kej mohyly z doby halštatskej vo Včelinciach, okr. Rimavská Sobota (obr. 9; Furmánek/Marková 1994, 388, obr. 24). Aj toto je doklad, že mohyla bola terénnou dominantou krajiny, ktorú populácie mladšej doby železnej evidovali a pritahovala ich pozornost', čo však podotkli už aj realizátori výskumu (Furmánek/Marková 2008, 85). Další ojedinelý žiarový a tiež urnový hrob bol zdokumentovaný $\mathrm{v}$ prírodnom mohylovitom útvare v Ratke, okr. Lučenec (Furmánek 1977; Furmánek/Sankot 1985, 273, 276). Oba zmienené keltské hroby sú datované do strednej doby laténskej (Repka 2014, 38).

\section{KELTI A VÝŠINNÉ HRADISKÁ Z KONCA DOBY BRONZOVEJ A ZO ZAČIATKU STARŠEJ DOBY ŽELEZNEJ}

Existujú prípady, ukazujúce na výskyt materiálu z doby laténskej na výšinných polohách a hradiskách, ktoré boli dominantne osídlené v dobe popolnicových polí, eventuálne v staršej dobe železnej. Zväčša to nie je prekvapujúce a uvedený fakt sa vysvetluje polykultúrnym osídlením lokality. Klasickým príkladom z územia rozšírenia kyjatickej kultúry je Zádielske hradisko (kóty 553 až 600) v k. ú. obce Háj, okr. Košice-okolie (Furmánek 1983, 30). Plošný výskum tejto impozantnej pravekej lokality s takmer 100 ha opevnenou plochou sa síce zatial' nerealizoval, avšak niekol'ko železných predmetov a grafitová keramika svedčia o osídlení a typických remeselných aktivitách aj v dobe laténskej (Bárta 1977, 390, 393). Novšie k týmto pribudli d’alšie nálezy (Pieta 2008, 21). Na stavbe a dobudo- vaní systému opevnenia, ktorý v teréne pozorujeme v súčasnosti, sa podla niektorých bádatelov s vel'kou pravdepodobnostou podielali i Kelti (Šška 1981, 290). V mladších stupňoch doby laténskej boli znovu obývané a čo sa týka opevnení zosilnené aj strategicky najvýhodnejšie hradiská kyjatickej kultúry na severe Mad’arska (napr. poloha Nagysánc v Bükkszentlászló; Matuz/Nováki 2002, 9, 10, 33-35). Celý rad polykultúrnych lokalít, osídlených tiež $\mathrm{v}$ dobe laténskej, by bolo možné menovat najmä z prostredia slovenskej lužickej kultúry.

Iný pohlad nastolujú ojedinelé alebo solitérne nálezy. Sporadické stopy osídlenia zo staršej až strednej doby laténskej sa zdokumentovali na taažko dostupnom výšinnom sídlisku a v princípe prírodnej pevnosti kultúr juhovýchodných popolnicových polí na dominantnom vrchu Hradová $(887 \mathrm{~m} \mathrm{n}$. m.) nad mestom Tisovec, okr. Rimavská Sobota (obr. 10; Bartík/Čambal 2014). Zo súboru zberových nálezov je pozoruhodná bronzová spona včasnolaténskej konštrukcie s vol'nou, tzv. vtáčou pätkou (obr. 10: 1a, 1b; Bartík/Čambal 2014, 96, 98, tab. I: 1a, 1b). Artefakt je vzhl'adom k poznatkom o osídlení Hradovej interpretovaný ako "stratový nález" z konca včasnej až zo staršej doby laténskej (Bartík/Čambal 2014, 99). K pertraktovanému okruhu nálezov z doby laténskej sa hlásia aj železné predmety $\mathrm{z}$ hradiska kyjatickej kultúry na vrchu Zámok pri Málinci, okr. Poltár (obr. 8: 9, 10, 12; Pieta 2008, 37, obr. 12: 8-10). Podotýkame, že z kopcovitého terénu v chotári Málinca, na vrchole výšiny Saské (588 m n. m.), evidujeme i železný keltský meč, nájdený zasunutý v železnej plechovej pošve. Tento dôležitý predmet je údajne ojedinelým nálezom a interpretovaný bol ako Keltmi „stratený“ (Čambal/Kovár 2014a, 199, 200, 206). ${ }^{2} \mathrm{~V}$ analyzovanom rámci výšinných hradísk z doby popolnicových polí registrujeme aj železný nôž z Marianky, polohy Barania lúka, okr. Malacky (Paulík 1996, 43, 44, obr. 2: 1). Ide o nožík s odlomenou rukovätou, nález zo sekundárnej polohy a podla dostupných informácií jediný železný artefakt z tohto náleziska (Hlavenková 2010, 33, 42). Myslíme si, že aj tento tvar železného noža má všeobecne bližšie k laténskym výrobkom tohto typu, než k nožom z mladšej doby bronzovej. Zároveň poznamenávame, že na západnej strane Malých Karpát, vzdušnou čiarou $30 \mathrm{~km}$ na severovýchod, v k. ú. obce Plavecké Podhradie (okr. Malacky) sa nachádza dôležité keltské hradisko Pohanská (Paulík 1976b). Význam tejto lokality v malokarpatskom regióne $\mathrm{v}$ dobe laténskej zrejme nemá význam zdôrazňovat', avšak za zmienku určite stojí, že práve na Pohanskej sa našiel aj celý rad železných nožov

\footnotetext{
2 Povšimnutiahodným „ojedinelým nálezom“ je aj železný meč z doby laténskej, ktorý sa našiel v roku 1886 na mohylovom pohrebisku z doby halštatskej na známej rakúskej lokalite Frög (Tomedi 2002, 115, tab. 101: 18).
} 


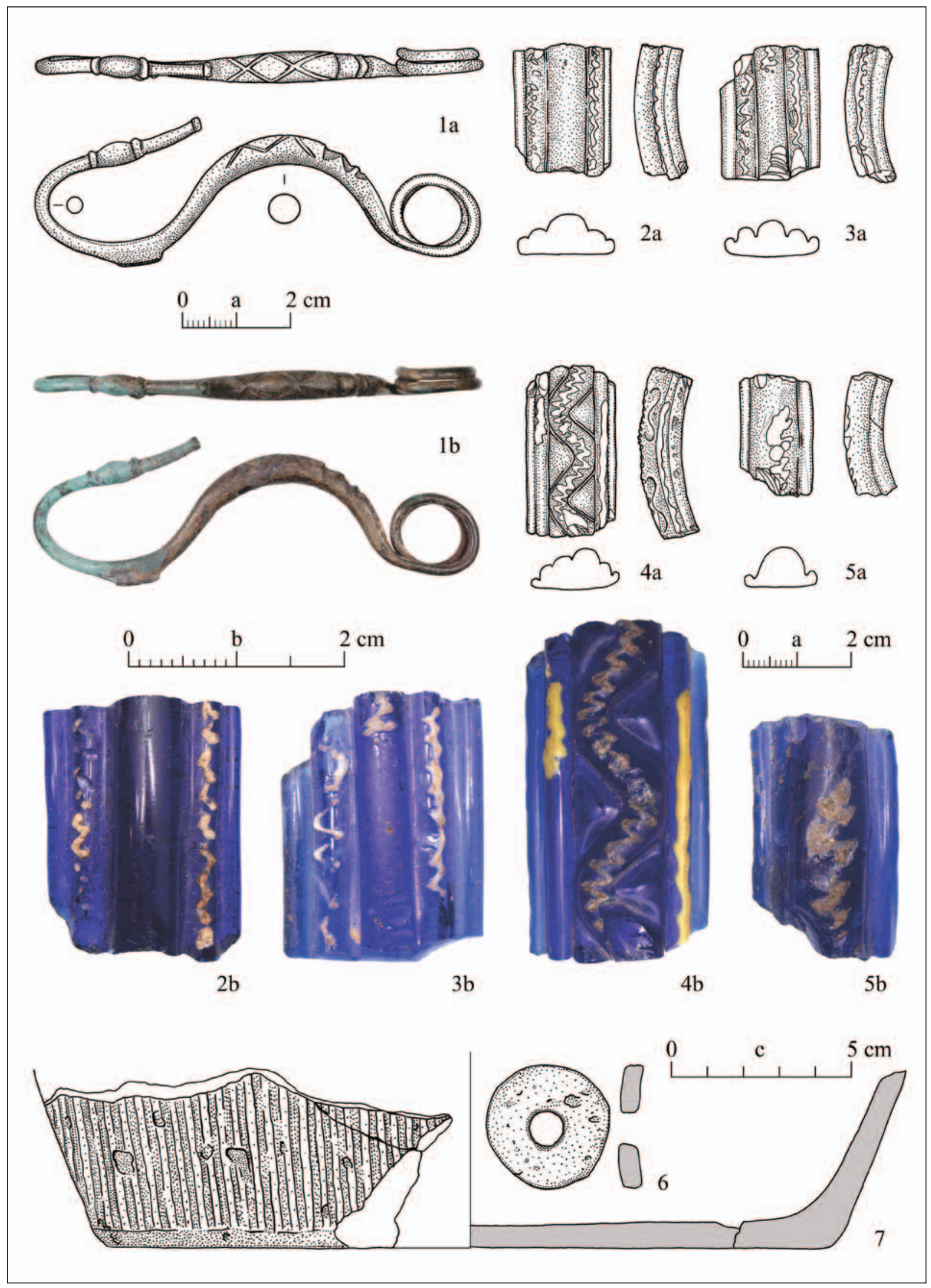

Obr. 10. Tisovec, poloha Hradová. Materiál z doby laténskej (Bartík/Čambal 2014, tab. I). 
viacerých variantov a ich zlomky (k nožu z Marianky pozri napr. Paulík 1976b, 115, 154, 155, tab. XLVIII: 11). Konštatovanie o sporadických stopách laténskeho osídlenia na výšinných polohách na Slovensku by sme ešte vedeli rozšírit o d’alšie príklady (Rybník-Krivín, okr. Levice; obr. 8: 7, 8; pozri napr. Pieta 2008, obr. 12; Veliačik/Srnka/Valo 2002, 40), avšak d’alej už obrátime pozornost’ na solitérne nálezy, ktoré $\mathrm{v}$ rámci analýzy aktivít Keltov na sledovanej kategórii lokalít z doby popolnicových polí považujeme za najrelevantnejšie.

Na ilustráciu uvádzame tri príklady. V 80. rokoch 20. stor. sa do archeologickej spisby uviedol ojedinelý nález laténskej bronzovej spony z výšinnej polohy Tureň (535 m n. m.) vo Vítkovciach, okr. Spišská Nová Ves (MiroššayoválJavorský 1986). Ide o typ spony s parabolicky klenutým lučíkom (obr. 8: 11), ktorý citovaní bádatelia rámcovo datovali do stupňa LTB. Z nášho hladiska je však podstatné, že na vrchu Tureň s hradiskom $\mathrm{z}$ doby popolnicových polí a ani v jeho blízkom okolí sa osídlenie zo staršej doby laténskej zatial' neeviduje (Miroššayovál Javorský 1986, 664; 1994, 21). Druhým príkladom je už spomínaná bronzová spona včasnolaténskej konštrukcie s volnou pätkou z Tisovca-Hradovej (obr. 10: 1a, 1b; Bartík/Čambal 2014, 96, 98, tab. I: 1a, $1 b)$, ktorá podl'a nášho predpokladu na lokalitu nebola „prinesená" spoločne s chronologicky mladšími predmetmi $\mathrm{v}$ strednej dobe laténskej a na uvedenej výšinnej polohe môže dokumentovat najstaršie aktivity Keltov, eventuálne jedny z najstarších v povodí Rimavy (Hutka/Bartík 2008). Podobné stopy aktivít zrejme dokumentujú tak včasnolaténske (obr. 8: 5, 6), ako aj strednolaténske nálezy na výšinnom pravekom hradisku Katova skala nad Sklabinským Podzámkom (Pieta/Veliačik 2014, 8). Mimoriadny je nález Ar tetradrachmy cudzej proveniencie z Pohanského vrchu (Pohanského hradu; kóta 595,3) v k. ú. obce Kotmanová (v druhej polovici 20. stor. Dobročská Lehota), okr. Lučenec (Kolníková 2003, 239, obr. 1: 49, tabela 1). Uvedená strieborná minca z 3./2. stor. pred n. l. sa totiž údajne našla (detektorom kovov?) na výšinnom hradisku kyjatickej kultúry z neskorej doby bronzovej, ktoré autori osobne a opakovane rekognoskovali, avšak materiál z doby laténskej na tejto lokalite neobjavili (Furmánek 1983, 28-30; Marková/Mitáš 2016). V súvislosti s nálezom Ar tetradrachmy z Pohanského vrchu v Kotmanovej sa žiada odbočit aj ku dvom keltským minciam (čast̉ depotu mincí?), ktoré sa našli v 19. stor. asi pod známou výšinnou lokalitou Pohanský hrad (Pogány vár) v Starej Bašte (Furmánek/Sankot 1985, 275). Ako sme už vyššie spomenuli, čast' plochy Pohanského hradu Kelti dokázatelne osídlili (Furmánek 1996, 128).

\section{AKTIVITY KELTOV \\ NA PRAVEKÝCH LOKALITÁCH V OKOLITÝCH KRAJINÁCH}

V úvode sme uviedli, že doklady materiálnej kultúry z doby laténskej vo všeobecnosti interpretované ako aktivity Keltov na pravekých lokalitách, sú predmetom systematického záujmu českých bádatelov. Viaceré z týchto aktivít sa konštatovali na žiarových pohrebiskách alebo $\mathrm{v}$ mohylách $\mathrm{z}$ doby bronzovej (vrátane kultúr popolnicových polí) a doby halštatskej, ale aj na výšinných hradiskách z týchto dôb vo viacerých regiónoch Česka. Niektoré si pripomenieme, hoci väčšina $z$ nich bola v rôznych prehladoch už diskutovaná.

Zlomky typickej laténskej keramiky, rámcovo datované od LTB2/C1-LTD, sa uvádzajú zo žiarového pohrebiska lužickej kultúry Malá Bělá (nateraz súčast' obce Bakov nad Jizerou), okr. Mladá Boleslav (Waldhauser 1999, 163). Pozornost' vzbudzuje aj grafitová keramika z mladších stupňov doby laténskej na žiarovom pohrebisku $\mathrm{z}$ konca praveku v chotári obce Nynice (v súčasnosti čast’ obce Hromnice), okr. Plzeň-sever (Šaldová 1971, 5, 88, obr. 50: 5-7; pozri tiež John 2003, 81). Početné laténske nálezy pochádzajú zo žiarových hrobov lužickej kultúry na pohrebisku Chodouny, okr. Litoměřice. Miesto pohrebiska však bolo využité $\mathrm{v}$ dobe laténskej na sídelné účely, a teda nie je vel’mi prekvapujúce, že niektoré hroby z doby popolnicových polí Kelti mechanicky narušili, alebo sa $\mathrm{v}$ nich konštatuje intrúzia laténskeho materiálu (Trefný/Jirán̆ a kol. 2012, 11-13, 74, 76, 80, 83, 84). Chodouny na tomto mieste uvádzame zámerne a hodláme tým zvýraznit nálezovú situáciu na žiarovom pohrebisku v Cinobani. Sídliskový areál $\mathrm{z}$ doby laténskej $\mathrm{v}$ polohe Jarčanisko II (tiež Krivé zeme), na rozdiel od stratigraficky zložitejšej situácie na menovanom českom nálezisku, je totiž od cinobanského pohrebiska pilinskej a kyjatickej kultúry vzdialený asi $500 \mathrm{~m}$ (obr. 11). Z hladiska tejto témy sú pozoruhodné tiež dlhší časový úsek využívané žiarové pohrebiská - na mysli máme dobu popolnicových polí až dobu halštatskú -, na ktorých sa pochovávalo aj v dobe laténskej. $\mathrm{K}$ takýmto patrí napr. Bischofshofen-Pestfriedhof v salzburskom regióne, kde sa identifikovalo niekol'ko hrobov z včasnej, ale aj z neskorej doby laténskej (Lippert/Stadler 2009, 11, 197, 203). Za zmienku ešte stojí, že na tejto rakúskej lokalite sa zdokumentovali podobné kamenné hrobové konštrukcie a toto pohrebisko má charakter ako Cinobaňa.

Zvlášt interesantné a najmä detailne a najnovšími archeologickými metódami zdokumentované zásahy Keltov z mladej až neskorej doby laténskej sa v ostatnom čase zverejnili v kamennej konštruk- 


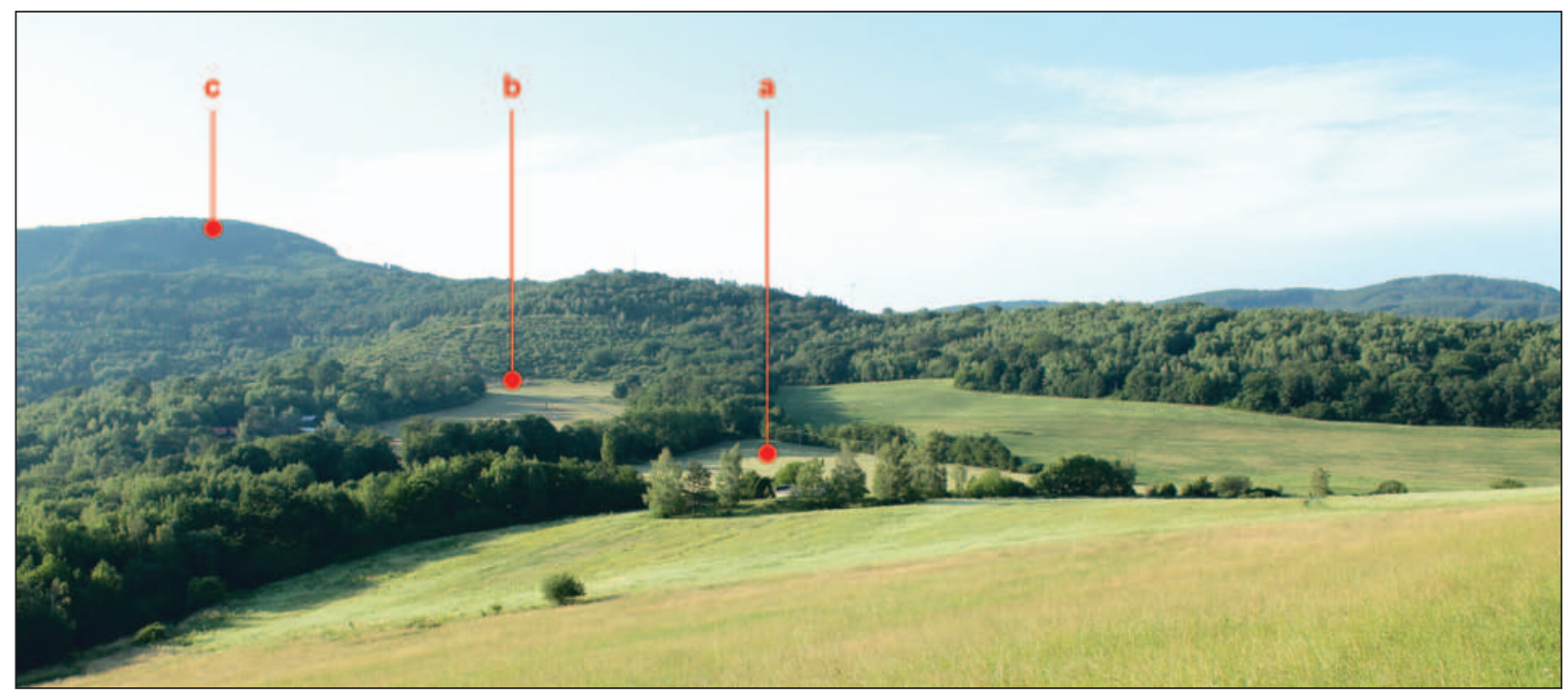

Obr. 11. Cinobaňa. Komplex archeologických nálezísk. Legenda: a - sídlisko z doby popolnicových polí a z doby laténskej; b - pohrebisko z doby popolnicových polí s dokladmi laténskych aktivít; c - hradisko z neskorej doby bronzovej.

cii kniežacej mohyly 1 z neskorej doby halštatskej v k. ú. obce Rovná, okr. Strakonice. Kelti v tomto prípade "nahliadli“ aj do vnútra kamennej hrobovej komory a narušili bohatý halštatský inventár (Chytráček a i. 2017a; 2017b; Michálek 2017a, 362). Fakt, že na juhu Čiech nejde o osobitne spozorovaný exces, potvrdzuje nálezová situácia $\mathrm{v}$ halštatskej mohyle I v chotári Babína u Horaždovic, okr. Klatovy (Michálek 2017a, 46-48; 2017c, tab. 7; 8), ale aj iné (pozri napr. Michálek 2017b, 429). V súčasnosti je v južných Čechách materiál zo stupňov LTB-LTC/D známy v mohylách $\mathrm{z}$ doby bronzovej a doby halštatskej na viac než 30 lokalitách! Ďalšie nálezy z tejto kategórie sa evidujú $\mathrm{v}$ západných a stredných Čechách (Chytráček a i. 2017a, 345-348, obr. 6; Michálek 2017a; 2017b; 2017c). Z južných Čiech nechýba ani doklad uloženia keltského hrobu do mohylovitého útvaru prírodného pôvodu (nález na k. ú. mesta Netolice, okr. Prachatice; John a i. 2015a), čo z hladiska výberu hrobového miesta čiastočne pripomína vyššie citovaný laténsky hrob z Ratky na juhu stredného Slovenska (Furmánek 1977). Keltské hroby v starších mohylách, resp. v areáloch od praveku využívaných mohylníkov, sú zdokumentované aj na území dnešného Mad’arska (Kiszombor C, poloha Nagyhalom, v Potisí, ale aj iné lokality; Furmánek/Sankot 1985, 276; Tankó 2015) alebo na susednej Morave (Borotice, okr. Znojmo; Čižmářová/Stuchlík 2014).

Potom existuje celý rad ojedinelých laténskych nálezov - železné spony, sklené náramky (spravidla ich zlomky), keramické úlomky a d’alšie artefakty, ktoré svedčia o aktivitách Keltov na výšinných hradiskách z praveku a nezriedka na prírodných dominantách krajiny. Aj tieto sú velmi dobre zmapované práve českými bádatelmi (bez menovania jednotlivých lokalít bližšie napr. Chytráček 1995, 118-121; Chytráček/Metlička 2004, 29, 30; John 2003, 79, 80; Waldhauser 1992; 2002; Waldhauser/Koldová 2006). Výnimočne sú v pravekých mohylách doložené nálezy keltských mincí (Drdal Rybová 1998, 176; Chytráček a i. 2017a, 346, 348; John a i. 2015b, 146).

\section{VYHODNOTENIE, ÚVAHY, ZÁVER}

Cinobaňa a Radzovce nie sú na Slovensku osamotenými lokalitami z doby popolnicových polí, na ktorých sú zjavné aktivity Keltov. Analýza dokladov materiálnej kultúry z doby laténskej z týchto dvoch, ale aj z radu d’alších nálezísk z mladších stupňov doby bronzovej, prípadne zo staršej doby železnej, tieto aktivity dovoluje kategorizovat a špecifikovat: a) ojedinelé nálezy (kovových, sklených predmetov a keramiky) na "plochých“ žiarových pohrebiskách, mohylových pohrebiskách a v mohylách (napr. Cinobaňa, Radzovce, Krásna Ves, Sklabinský Podzámok, Cabaj-Čápor);

b) ojedinelé hroby alebo skupinky hrobov v násypoch samostatne stojacich mohýl z mladšieho praveku (napr. Palárikovo II, Včelince, Chotín V), prípadne $\mathrm{v}$ mohylovitých útvaroch prírodného pôvodu (Ratka);

c) ojedinelé alebo solitérne nálezy (keramiky, kovových spôn, železných nožov, sklených náramkov, mincí) z výšinných hradísk, resp. z polôh s viditel'nou fortifikáciou (napr. Marianka-Barania 
lúka, Málinec-Zámok, Vítkovce-Tureň, Kotmanová-Pohanský vrch); 3

d) sporadické nálezy alebo doklady krátkodobého osídlenia/využitia dominantných výšinných polôh, resp. prírodných dominánt v krajine (napr. Tisovec-Hradová, Sklabinský Podzámok-Katova skala, Rybník-Krivín);

e) hromadné nálezy železných predmetov a mincí mimo stabilné sídliskové areály z doby laténskej (Cinobaňa a pravdepodobne aj Stará Bašta).

Z kategorizácie dokladov materiálnej kultúry Keltov na pravekých lokalitách na Slovensku, no najmä v priestore osídlenom kultúrami doby popolnicových polí a doby halštatskej, vyplýva predovšetkým ich spojitost' s viditelnými terénnymi objektmi, akými sú mohylové násypy na pohrebiskách, samostatne stojace mohyly - terénne dominanty reliéfu, kamenné alebo zemné valy na výšinných sídliskách, poprípade dominantné útvary a impozantné výšiny v krajine. Obdobné skutočnosti spozorovali aj českí bádatelia (napr. John 2003, 81, 82). Analyzované nálezy sú teritoriálne späté tak s klasickou keltskou ekuménou (Cinobaňa, Radzovce, Včelince, Chotín V, Palárikovo II atd'), ako aj s keltizovaným územím púchovskej kultúry (Krásna Ves, Sklabinský Podzámok, Vítkovce). Chronologicky nie sú striktne rámcované a všeobecne korešpondujú s poznatkami o osídlení v dobe laténskej na Slovensku a strednom Dunaji vôbec (pozri napr. Čambal/Kovár 2014b, 311, 312; Pieta 2008, 17-65, obr. 24; Repka 2014, obr. 7).

Doteraz sme rozmýšlali predovšetkým nad aktivitami Keltov v Cinobani (Furmánek/Mitáš 2011a, 121; 2014, 101). Konštatovalo sa, že nielen spôsoby deponovania vybraných železných artefaktov (tak hromadného nálezu s masívnym kladivom, kladivkom a kramlou, ako aj zdeformovanej železnej spony; obr. 1; 2: 1, 3), ale aj ich zvýšená koncentrácia na relatívne malom priestore s geniom loci, môže poukazovat' na kultové aktivity Keltov v „prírodnom sanktuáriu“. Teraz ešte raz zdôrazňujeme, že žiarové hroby z doby popolnicových polí boli aj v čase výskumu identifikované relatívne plytko pod nánosom hliny a drobných kameňov z horných partií svahu a zarastené trávou či náletovými drevinami. Je celkom pravdepodobné, že dominantné kamenné skrinky a kamenné násypy nad skrinkami boli v dobe laténskej ešte postrehnutelné a vzbudili pozornost' Keltov, ktorí na území Cinobane obývali identický priestor ako ich predchodcovia - populácia z doby popolnicových polí. Miesto, na ktorom Kelti pochovávali, však doposial' nepoznáme. Dodávame, že materiál z doby laténskej sa zatial' nezistil ani na výšinnom hradisku kyjatickej kultúry na Striebornej (719 m n. m.; Furmánek/Mitáš 2011b, 96). Ďalej sa uvažovalo, že porušovanie kamenných hrobových konštrukcií (obr. 6) a zvýšený výskyt železných predmetov vrátane železnej trosky a lupy (obr. 5: 1-3) na ploche pravekého pohrebiska však môže odzrkadlovat' aj profánne aktivity Keltov. Položili sme si aj otázku, či azda niekde blízko preskúmanej plochy žiarového pohrebiska sa nenachádza železiarsky výrobný objekt z doby laténskej (Furmánek/Mitáš 2011a, 122; 2014, 102). ${ }^{4}$ Niektoré železné artefakty, napr. troska z nadložia hrobu 217/11, sa totiž na miesta, v ktorých sme ich na svahovitej ploche pohrebiska identifikovali, mohli dostat eróziou.

Medzi bádatel’mi existuje všeobecná zhoda, že deponovanie hromadných nálezov alebo jednotlivých predmetov na najrôznejších miestach malo najrôznejšie príčiny (Michálek 1999, 47-55; Pieta 2008, 192, 193, 204-210; Venclová 2008, 93, 94). V prípade žiarového pohrebiska v Cinobani preferujeme názor o rituálnych aktivitách Keltov mimo ich sídliskového areálu (obr. 11; 12). Pokial' niekolko skrinkových hrobov skutočne otvorili už oni, význam „preskúmaných“ kamenných hrobových konštrukcií (kyjatickej kultúry) im musel byt zjavný. $S$ touto činnostou by mohli súvisiet i niektoré zlomky železných predmetov - (zo zničených) nástrojov na kutanie (?). Došlo v tejto súvislosti aj k rituálnemu vyzdvihnutiu spálených kostí? V skrinkových hroboch 62/09 a 160/10 (obr. 6: 1, 2, 5, 6) sa totiž nezistili ani urny, ani kremačné zvyšky. S ohl'adom na doterajšie výsledky výskumu v polohe Jarčanisko sa domnievame, že vybrané a najmä vyššie opísané tvarovo typické železné artefakty boli darované „(pra)predkom“, s ktorými zdielali identický sídliskový areál (poloha Jarčanisko II, resp. Krivé zeme; obr. 11), a preto by mohli byt' spojené so sférou súvekej religiozity. ${ }^{5}$ Argumentáciu sčasti podporuje aj miniatúrna sekerka zo železa (obr. 4), ktorá má v zahraničí vyššie citované analógie v súvekých votívnych daroch (Kiernan 2009).

\footnotetext{
3 Ojedinelé nálezy z doby laténskej sa evidujú aj z jaskýň na Slovensku (podrobnejšie Struhár 2014). Niektoré boli už predmetom záujmu obyvatel'stva doby popolnicových polí (napr. jaskyne v Slovenskom krase).

4 Alebo z novoveku? Považujeme za korektné v tejto súvislosti spomenút, že na ploche pohrebiska sa v dvoch prípadoch našla aj novoveká keramika, fragment keramickej fajky alebo minca z 19. stor. V prípade železnej lupy a trosky si uvedomujeme, že nejde o typické „rituálne deponáty“ Keltov.

5 Tento predpoklad vo všeobecnosti nie je v rozpore ani s predstavami Keltov o smrti a mŕtvych (podrobnejšie Vlčková 2002, 163-168).
} 


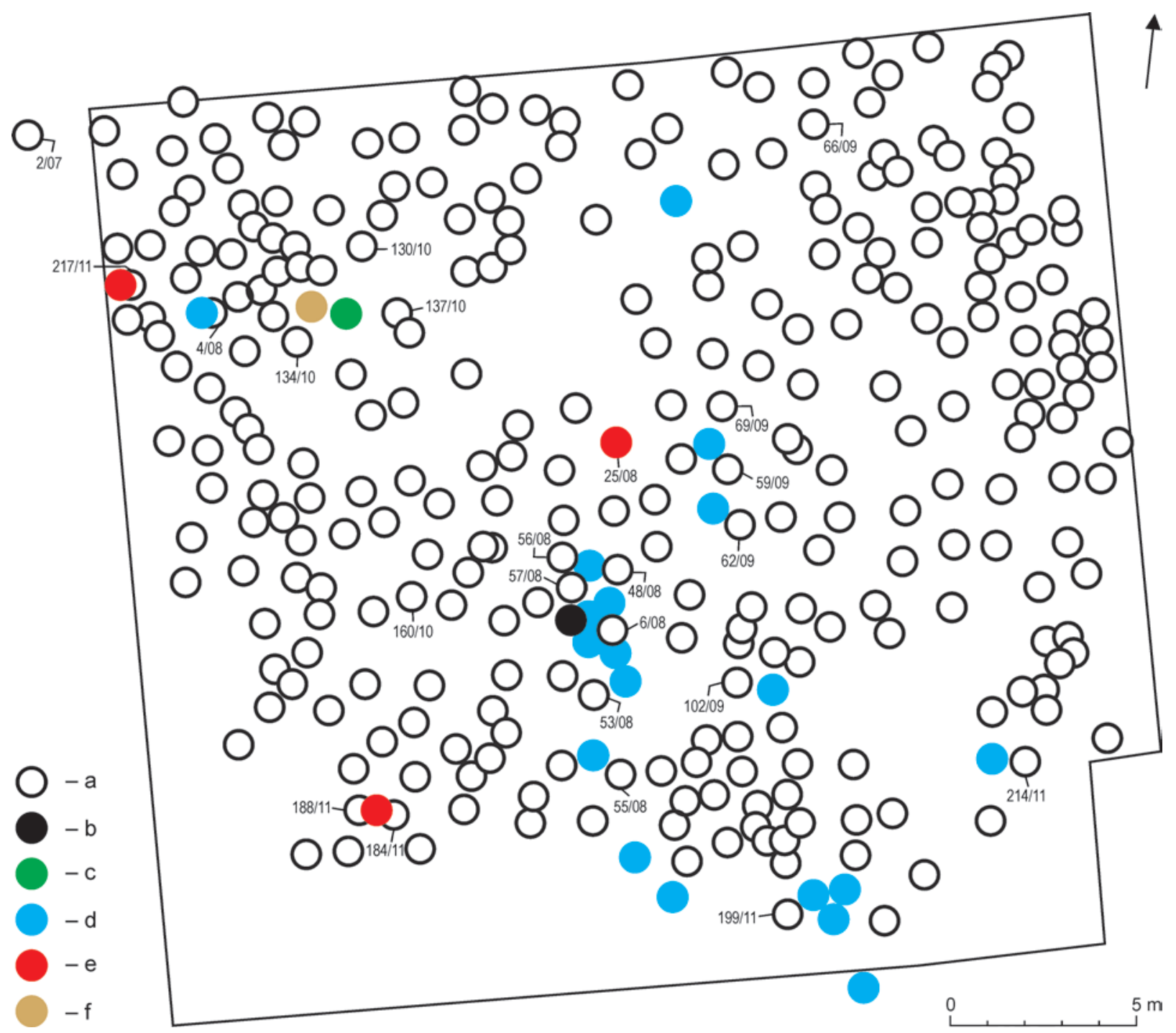

Obr. 12. Cinobaňa, poloha Jarčanisko. Výskyt artefaktov z doby laténskej na žiarovom pohrebisku kultúr popolnicových polí (plocha preskúmaná v rokoch 2008-2013; hrob 2/07 sa nachádzal mimo tejto plochy). Legenda: a - žiarový hrob; b - depot železných predmetov; c - železná spona; d - železný predmet alebo drobný zlomok; e - železná lupa a troska; $\mathrm{f}$ - keramický fragment.

V rituálnej sfére doby laténskej (pozri napr. Pieta 2008, 149) v súčasnosti vidíme aj unikátny železný nôž z Radzoviec (obr. 7: 1). Čo sa týka Cinobane, tak nálezové okolnosti naznačujú, že nejde o deponáty uložené naraz, ale na rôznych miestach pohrebiska postupne (obr. 12), čo odzrkadluje aj širšie datovanie súboru železných predmetov od stupňa LTC1 až do LTD. V zhode s vyššie citovanými autormi podotýkame, že deponovanie predmetov $\mathrm{v}$ tomto časovom úseku nie je v širšej strednej Európe zriedkavé (Kysela/Venclová 2018, 133, 137).

Zodpovedanie skutočnej motivácie uloženia väčšiny laténskych predmetov na analyzovaných lokalitách (obr. 13) bude zrejme vždy komplikovat celý rad otázok. Skôr s duchovnou sférou tieto doklady keltských aktivít spájajú aj českí bádatelia (Waldhauser 1999, 163; 2001, 175). Vedecky akceptovatelná je hypotéza o tzv. materiálnej pamäti komunít (bližšie Neustupný 1997, 226), ktorou sa žijúce spoločenstvo $\mathrm{v}$ krajine identifikovalo so svojimi mýtickými predkami, poprípade týmto pamätovým médiom dochádzalo $\mathrm{k}$ hlbšiemu osvojeniu si osídleného teritória so zretelom na jeho minulé obyvatel'stvo (Drda/Rybová 1998, 176; Chytráček 1995, 121, 123; Chytráček a i. 2017a, 345; John 2003, 82). S uvedenou hypotézou sa stotožňujeme najmä čo sa týka aktivít Keltov na pohrebiskových lokalitách, kde boli zjavné kamenné skrinky, príkrovy, mohylové násypy, resp. šlo o samostatne stojace vel'ké mohyly. Týkajú sa rituálne praktiky spojené s keltským 


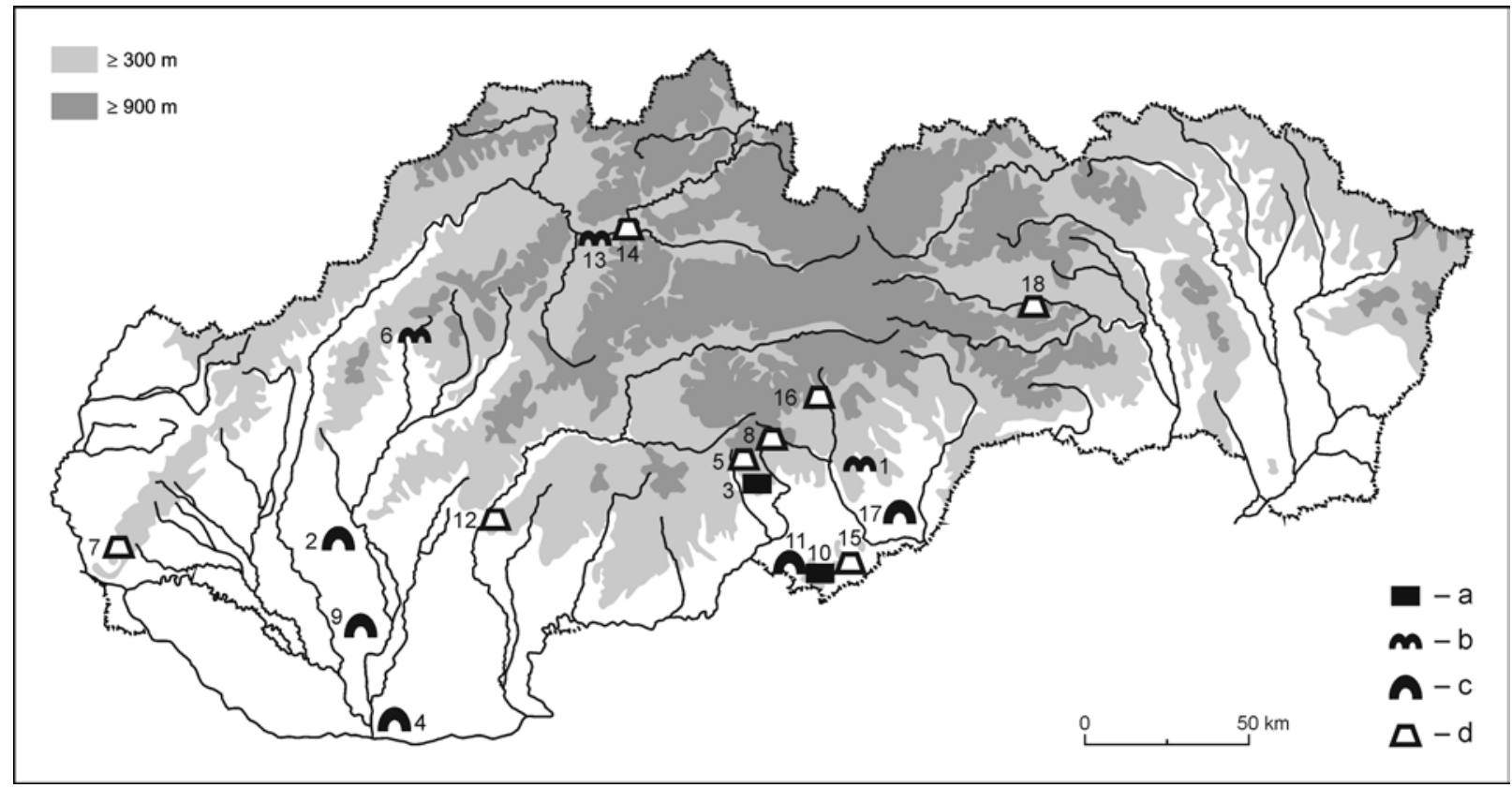

Obr. 13. Lokality z doby popolnicových polí a doby halštatskej so stopami keltských aktivít (v abecednom poradí). 1 - Babinec, poloha „,severovýchodne od obce“; 2 - Cabaj-Čápor, časť Čápor, poloha Pri kopci; 3 - Cinobaňa, poloha Jarčanisko; 4 - Chotín V, poloha Sashegy; 5 - Kotmanová, poloha Pohanský hrad (Pohanský vrch); 6 - Krásna Ves, poloha Pieskovisko; 7 - Marianka, poloha Barania lúka; 8 - Málinec, poloha Zámok; 9 - Palárikovo II, poloha Kopcová remíza; 10 - Radzovce, poloha Monosa; 11 - Ratka, čast' Malá Ratka, poloha „na pravom brehu Babského potoka“; 12 - Rybník, poloha Krivín; 13 - Sklabinský Podzámok, poloha „ústie Kantorskej doliny“; 14 - Sklabinský Podzámok, poloha Katova skala; 15 - Stará Bašta, poloha „okolie Pohanského hradu“; 16 - Tisovec, poloha Hradová; 17 - Včelince, poloha Halomszer; 18 - Vítkovce, poloha Tureň. Legenda: a - žiarové pohrebisko; b-žiarové pohrebisko mohylového typu; c - samostatne stojaca mohyla/prírodný mohylovitý útvar; d - hradisko/výšinná poloha.

kultom predkov napr. aj obrovskej mohyly z doby halštatskej v Regöly na území mad’arského Zadunajska (Stegmann-Rajtár 2014, 109, 110)? A vlastne, ako velmi bolo uctievanie "(pra)predkov“ a s ním spojené manipulácie s rozličnými predmetmi (alebo aj s ludskými pozostatkami) v dobe laténskej vo vnútri Karpatskej kotliny rozšírené? Predložené stopy aktivít z mladšej doby železnej ukazujú, že tieto osobité rituálne praktiky neboli tabu ani na území dnešného Slovenska. V tomto ohlade je uchopitelná i myšlienka Jozefa Paulíka, ktorú vyslovil v súvislosti s analýzou železného noža z Marianky ${ }^{6}$ (teda nepriamo k nami analyzovanému materiálu), avšak vzhladom na problematiku vzdávania holdu predkom u Keltov je pre nás podnetná: „Hlavné trasy oboch staršich vln, posledného vel'kého st'ahovania indoeurópskych národov' boli napokon zhruba totožné s neskoršimi keltskými pohybmi na juh a juhozápad. A ako ,predlohy' sa uvádzajú i v prácach s keltskou problematikou v celoeurópskom rámci." (Paulík 1996, 53). Tušili toto tiež Kelti? Nemyslíme si však, že $\mathrm{v}$ príspevku zhodnotené miesta by bolo vhodné porovnávat’ s "klasickými“ prírodnými loci con- secrati a už vonkoncom nie s terénne vymedzenými (ohradenými) kultovými miestami - svätyňami, aké poznáme na teritóriách západne od Slovenska a najmä v západnej Európe (pozri a porovnaj napr. Brunaux 2012; Filip 1995, 165-174; Kysela/Venclová 2018, 125-131; Wieland 2012). O špecifickom mieste $\mathrm{v}$ tomto kontexte by azda bolo možné uvažovat v prípade keltského "kultového komplexu“ v Palárikove II (Paulikk/Zachar 1975).

$S$ ohladom na zámerne narušené skrinkové hroby a d’alšie aktivity z doby laténskej na pohrebisku z doby popolnicových polí v Cinobani vôbec premýšlame, či bolo Keltom aj v prípade výšinných opevnených lokalít na krajinných dominantách zjavné, že ide o opustené či zaniknuté sídla miestnych elít, resp. ich predkov? Premietali si Kelti „,staré" mohyly a fortifikácie aj do súvekých mýtických príbehov o krajine predkov? Pravda, podobnými otázkami sa už vzd'alujeme od archeologickej podstaty analyzovanej problematiky. Interpretačný rámec ojedinelých alebo sporadických nálezov, ktoré sa od včasnej doby laténskej (a niekedy aj opakovane v strednej až neskorej dobe laténskej)

\footnotetext{
6 Vyššie sme tento artefakt zámerne spomenuli a domnievame sa, že patrí do doby laténskej.
} 
objavujú na výšinných (opevnených) polohách osídlených od praveku, je všeobecne širší. V (pod) horských oblastiach a na tažšie dostupných alebo mimoriadnych miestach, pochopitelne, okrem rituálnych praktík do úvahy prichádzajú vysvetlenia aj profánneho charakteru ako sú prospekcia krajiny spojená s vyhladávaním surovín, sezónne pastierstvo, využívanie refugiálnych, signálnych či strážnych polôh a iné ( $\mathrm{k}$ téme viac Waldhauser 2002, 330, 338-342; 2012, 292, 293; Waldhauser/Koldová 2006, 588-592). V rámci keltských aktivít na spomínaných hradiskách v Málinci, Tisovci, Vítkovciach a d’alších síce možno mysliet’ aj na straty predmetov, avšak túto možnost' berieme na zretel' až v poslednom rade. O prieskumných aktivitách Keltov však treba uvažovat' $\mathrm{v}$ súvislosti s osídlovaním krajiny ako takej, pričom snahu o bližšie spoznanie orientačne dôležitých alebo strategicky výhodných výšinných polôh, na ktorých z času na čas objavili aj rukolapné stopy staršieho osídlenia, považujeme za celkom prirodzenú. Svedčí o takýchto aktivitách napr. železný meč z Málinca? Možnosti interpretácie jednotlivých ojedinelých laténskych nálezov, samozrejme, podstatne ovplyvňuje najmä celkové prebádanie a poznanie náleziska a prilahlej oblasti, medzi ktorými existuje väzba. Lokality, ktoré sme v príspevku zohl’adnili (obr. 13), s najväčšou pravdepodobnostou podávajú svedectvo, že viditel'né relikty z praveku v krajine na severe Karpatskej kotliny, a teda na súčasnom Slovensku, historickí Kelti nielen intenzívne vnímali, ale v niektorých prípadoch asi aj spájali so svojou minulostou.

\section{LITERATÚRA}

Almássy 2005-K. Almássy: Szabolcs-Szatmár-Bereg megye szkíta és kelta korának kutatástörténete. Satu Mare. Studii şi comunicări. Arheologie 22/1, 2005, 99-106.

Bartík/Čambal 2014 - J. Bartík/R. Čambal: Laténske nálezy z Tisovca-Hradovej, okr. Rimavská Sobota. Zborník SNM 108. Archeológia 24, 2014, 95-101.

Bárta 1977 - J. Bárta: Zádielska dolina od praveku po oslobodenie. Krásy Slovenska 9, 1977, 388-393.

Brunaux 2012 -J.-L. Brunaux: Gefasste Heiligtümer. Opferund Versammlungsplätze. In: R. Röber et al. (Hrsg.): Die Welt der Kelten. Zentren der Macht. Kostbarkeiten der Kunst. Ostfildern - Konstanz 2012, 285-291.

Březinová 2006 - G. Březinová: Sídliská a sídliskové nálezy z laténskej doby na juhozápadnom Slovensku. Študijné zvesti Aú SAV 40, 2006, 9-50.

Březinová 2018 - G. Březinová: Šperk zo skla a sapropelitu u Keltov na Slovensku. Archaeologica Slovaca Monographiae. Studia 30. Nitra 2018.

Budinský-Krička/Veliačik 1986 - V. Budinský-Krička/L. Veliačik: Krásna Ves. Gräberfeld der Lausitzer Kultur. Materialia Archaeologica Slovaca 8. Nitra 1986.

Čambal 2009 - R. Čambal: Nové nálezy z doby laténskej z Plaveckého Podhradia-Pohanskej. Zborník SNM 103. Archeológia 19, 2009, 153-164.

Čambal/Kovár 2014a-R. Čambal/B. Kovár: Keltský meč z Málinca (okr. Poltár). Pravěk. Nová řada 21, 2014, 199-208.

Čambal/Kovár 2014b - R. Čambal/B. Kovár: Keltské nálezy z Čeboviec (okr. Vel'ký Krtíš) a ich regionálne postavenie. In: Čižmářová/Venclová/Břrezinová 2014, 305-314.

Čižmář 1996 - M. Čižmář: Neue Erkenntnisse über die Spätlatènezeit in Mähren. In: E. Jerem/A. Krenn-Leeb/J.-W. Neugebauer/O. H. Urban (Hrsg.): Die Kelten in den Alpen und an der Donau. Akten des Internationalen Symposions St. Pölten, 14.-18. Oktober 1992. Budapest - Wien 1996, 359-369.

Čižmářová/Stuchlík 2014 -J. Čižmářová/S. Stuchlík: Laténské pohřebiště v Boroticích (okr. Znojmo). In: Čižmářrovál VencloválBřezinová 2014, 471-486.

Čižmářová/Venclová/Březinová 2014 - J. Čižmářová/N. Venclová/G. Březinová (ed.): Moravské křižovatky. Střední Podunají mezi pravěkem a historií. Brno 2014.
Drda/Rybová 1998 - P. Drda/A. Rybová: Keltové a Čechy. Praha 1998.

Dušek 1961 - M. Dušek: Kotázkam pravekého vývoja juhozápadného Slovenska. Študijné zvesti AÚ SAV 6, 1961, 59-82.

Filip 1995 - J. Filip: Keltská civilizace a její dědictví. Nové rozširené vydání. Praha 1995.

Furmánek 1975 - V. Furmánek: Další nálezy na halštatském a laténském pohřebišti v Drni. AVANS 1974, 1975, 48, 49.

Furmánek 1977 - V. Furmánek: Laténský žárový hrob z Ratky. AVANS 1976, 1977, 104, 105, 337.

Furmánek 1983 - V. Furmánek: Hradiská pilinskej a kyjatickej kultúry na Slovensku. Archeologické rozhledy 35, 1983, 24-32.

Furmánek 1984 - V. Furmánek: Revizní výzkum v Babinci. AVANS 1983, 1984, 77, 78, 258.

Furmánek 1985 - V. Furmánek: Božena Němcová a archeologie Gemeru. Obzor Gemera 16, 1985, 173-175.

Furmánek 1988 - V. Furmánek: Eisen während der Bronzezeit in der Slowakei. Zeitschrift für Archäologie 23, 1988, 183-189.

Furmánek 1990 - V. Furmánek: Radzovce. Osada l'udu popolnicových polí. Archeologické pamätníky Slovenska, zväzok 1. Bratislava 1990.

Furmánek 1996 - V. Furmánek: Komplexný archeologický prieskum Pohanského hradu nad Starou Baštou. Obzor Gemera-Malohontu 25, 1996, 126-130.

Furmánek 2010 - V. Furmánek: Radzovce. Osada l’udu popolnicových polí. Ragyolc. Az urnamezős kultúra népének települése. Zväzok 1 - druhé vydanie. Archeologické pamätníky Slovenska. Nitra 2010.

Furmánek 2019 - V. Furmánek: Radzovce in der Zeit der Urnenfelderkulturen (Katalog der Siedlung). Archaeologica Slovaca Monographiae. Catalogi 20. Nitra 2019.

Furmánek/Marková 1994 - V. Furmánek/K. Marková: Revízny výskum mohyly z doby železnej vo Včelínciach. Slovenská archeológia 42, 1994, 369-397.

Furmánek/Marková 2008 - V. Furmánek/K. Marková: Včelince. Archív dávnej minulosti. Archeologické pamätníky Slovenska 9. Nitra 2008.

Furmánek/Mitáš 2010a - V. Furmánek/V. Mitáš: Cinobaňa - eine weitere bedeutende Fundstelle aus der 
Urnenfelderzeit in der Slowakei. Das Altertum 55, 2010, 33-58.

Furmánek/Mitáš 2010b - V. Furmánek/V. Mitáš: Pohřební ritus západní enklávy jihovýchodních popelnicových polí. Analýza pohřebiště v Radzovcích (Slovensko). Památky archeologické 101, 2010, 39-110.

Furmánek/Mitáš 2011a - V. Furmánek/V. Mitáš: Ein Gräberfeld des Volkes der Urnenfelderkultur als Gegenstand der Interessen von Kelten. (Was machten die Kelten in Cinobaňa?) Anodos. Studies of the Ancient World 11, 2011, 111-122.

Furmánek/Mitáš 2011b - V. Furmánek/V. Mitáš: Prieskum hradiska Strieborná. AVANS 2008, 2011, 96, 97, 302, 303.

Furmánek/Mitáš 2013 - V. Furmánek/V. Mitáš: Pokračovanie výskumu v Cinobani. AVANS 2009, 2013, 101, 102.

Furmánek/Mitáš 2014 - V. Furmánek/V. Mitáš: Pohřebiště lidu popelnicových polí předmětem zájmu Keltů. Co dělali Keltové v Cinobani? Studia Archaeologica Brunensia 19, 2014, 93-104.

Furmánek/Mitáš 2019 - V. Furmánek/V. Mitáš: Siedma sezóna výskumu pohrebiska v Cinobani. AVANS 2014, 2019, 60, 61.

Furmánek/Mitáš/Budaváry 2016 - V. Furmánek/V. Mitáš/ V. Budaváry: Radzovce in der Zeit der Urnenfelderkulturen (Katalog des Gräberfeldes). Archaeologica Slovaca Monographiae. Catalogi 16. Nitra 2016.

Furmánek/Sankot 1985 - V. Furmánek/P. Sankot: Nové laténské nálezy na středním Slovensku. Slovenská archeológia 33, 1985, 273-310.

Gruber 2015 - H. Gruber: Prähistorische Depotfunde in Oberösterreich - Ein Überblick. Fines Transire 24, 2015, 67-85.

Hellebrandt 1999 - M. Hellebrandt: Celtic Finds from Northern Hungary. Corpus of Celtic Finds in Hungary 3. Budapest 1999.

Hlavenková 2010 - L. Hlavenková: Hradisko kultúry stredodunajských popolnicových polí v Marianke - 1. čast’ (typologicko-chronologická analýza). Zborník SNM 104. Archeológia 20, 2010, 33-45.

Horňák 2005 - M. Horňák: Pohrebisko lužickej kultúry v Sklabinskom Podzámku. Slovenská archeológia 53, 2005, 203-218.

Hutka/Bartík 2008 - D. Hutka/J. Bartík: Prví Kelti v údolí Rimavy. Reussia 5, 2008, 19, 20.

Cheben 2015 - M. Cheben: Geofyzikálna prospekcia na Slovensku v rokoch 2010 až 2014. Študijné zvesti AÚ SAV 57, 2015, 111-139.

Chytráček 1995 - M. Chytráček: Ojedinělý nález z mladší doby laténské na Černém vrchu u Svržna, okr. Domažlice. Archeologické rozhledy 47, 1995, 115-127.

Chytráček/Metlička 2004 - M. Chytráček/M. Metlička: Die Höhensiedlungen der Hallstatt- und Latènezeit in Westböhmen. Památky archeologické. Supplementum 16. Praha 2004.

Chytráček a i. 2017a - M. Chytráček/O. Chvojka/M. Egg/ J. John/R. Kyselý/J. Michálek/P. Stránská: Ein späthallstattzeitlicher Fürstengrabhügel bei Rovná in Südböhmen mit jüngeren Eingriffen aus der Jung- und Spätlatènezeit. In: J. Kysela/A. Danielisová/J. Militký (eds.): Stories that made the Iron Age. Studies in Iron Age Archaeology dedicated to Natalie Venclová. Praha 2017, 339-351.

Chytráček a i. 2017b - M. Chytráček/O. Chvojka/M. Egg/ J. John/R. Kozáková/R. Křivánek/R. Kyselý/J. Michálek/ P. Stránská: A Disturbed Late Hallstatt Period Princely
Grave with a Two-wheeled Chariot and Bronze Vessels in Sedlina Forest near Rovná in South Bohemia: a Preliminary Report. In: W. Irlinger/G. Suhr (eds.): Archaeological Sites in Forests. Strategies for their Protection. Schriftenreihe des Bayerischen Landesamtes für Denkmalpflege 14. München 2017, 83-90.

Jansová 1962 - L. Jansová: Konec jihočeských mohyl doby laténské. Památky archeologické 53, 1962, 306-330.

John 2003 - J. John: Spony, náramky, hradiště a mohyly. Př́iklad materiální paměti komunit doby laténské. In: L. Šmejda/P. Vařeka (red.): Sedmdesát neustupných let. Plzeň 2003, 79-84.

John a i. 2015a - J. John/M. Pták/E. Průchová/H. Hojerová/ V. Vondrovský: Laténský žárový pohřeb z "mohyly“ v lese Doubrava u Netolic. Živá archeologie 17, 2015, 10-14.

John a i. 2015b - J. John/J. Militký/O. Chvojka/M. Vlášek: Hromadný nález skordiských tetradrachem z Knína (okr. České Budějovice). Archeologické výzkumy v jižních Čechách 28, 2015, 139-150.

Kemenczei 2005 - T. Kemenczei: Funde ostkarpatenländischen Typs im Karpatenbecken. Prähistorische Bronzefunde XX/10. Stuttgart 2005.

Kiernan 2009 - P. Kiernan: Miniature Votive Offerings in the North-west Provinces of the Roman Empire. Mentor Studien zu Metallarbeiten und Toreutik der Antike 4. Wiesbaden 2009.

Kolníková 2003 - E. Kolníková: Fundmünzen in den latènezeitlichen Burgwällen und anderen Höhenlagen in der Slowakei. Slovenská archeológia 51, 2003, 223-246.

Kysela/Venclová 2018 - J. Kysela/N. Venclová: Duchovní svět Keltů. In: J. Militký/J. Kysela/M. Tisucká (ed.): Keltové. Čechy v 8. až 1. století pred Kristem. Praha 2018, 125-140.

Lippert/Stadler 2009 - A. Lippert/P. Stadler: Das spätbronze- und früheisenzeitliche Gräberfeld von BischofshofenPestfriedhof. 2 Teile. Universitätsforschungen zur prähistorischen Archäologie 168. Bonn 2009.

Marková/Mitáš 2016 - D. Marková/V. Mitáš: Výšinné opevnené sídlisko kyjatickej kultúry v Kotmanovej. AVANS 2011, 2016, 170-173.

Matuz/Nováki 2002 - E. D. Matuz/G. Nováki: Spätbronzezeitliche, früheisenzeitliche Erdwälle in Nordungarn. Inventaria Praehistorica Hungariae 10. Budapest 2002.

Michálek 1999 - J. Michálek: Keltský poklad z Bezdědovic na Blatensku. Blatná - Strakonice 1999.

Michálek 2017a-J. Michálek: Mohylová pohřebiště doby halštatské (HaC-D) a časně laténské (LTA) v jižních Čechách 1/1. Komentovaný katalog. Die Hügelgräberfelder der Hallstatt$(\mathrm{HaC}-\mathrm{D})$ und frühen Latènezeit (LTA) in Südböhmen 1/1. Kommentierter Katalog. Praha 2017.

Michálek 2017b - J. Michálek: Mohylová pohřebiště doby halštatské (HaC-D) a časně laténské (LTA) v jižních Čechách. 1/2. Komentovaný katalog - Die Hügelgräberfelder der Hallstatt- (HaC-D) und frühen Latènezeit (LTA) in Südböhmen 1/2. Kommentierter Katalog. Praha 2017.

Michálek 2017c - J. Michálek: Mohylová pohřebiště doby halštatské $(H a C-D)$ a časně laténské (LTA) v jižních Čechách. 1/3. Tabulky-Die Hügelgräberfelder der Hallstatt- $(\mathrm{HaC}-\mathrm{D})$ und frühen Latènezeit (LTA) in Südböhmen 1/3. Tafeln. Praha 2017.

Miroššayová/Javorský 1986 - E. Miroššayová/F. Javorský: Ojedinelý nález laténskej bronzovej spony z Vítkoviec. Archeologické rozhledy 38, 1986, 663-665.

Miroššayová/Javorský 1994 - E. Miroššayová/F. Javorský: Vítkovce - a Fortified Settlement from the Very Late 
Bronze Age. Pamiatky a múzeá. Special Issue. The Bronze Age in Slovakia, 1994, 19-21.

Mitáš/Furmánek 2015a-V. Mitáš/V. Furmánek: Tretia sezóna výskumu pohrebiska v Cinobani. AVANS 2010, 2015, 160-162.

Mitáš/Furmánek 2015b - V. Mitáš/V. Furmánek: Pohrebisko kultúrneho komplexu juhovýchodných popolnicových polí v Cinobani (Výskum v rokoch 2007-2012). In: O. Oždáni (ed.): Popolnicové polia a doba halštatská. Archaeologica Slovaca Monographiae. Communicationes 17. Nitra 2015, 159-189.

Neustupný 1997 - E. Neustupný: Uvědomování minulosti. Archeologické rozhledy 49, 1997, 217-230.

Paulík 1974 - J. Paulík: Výskum Archeologického ústavu Slovenského národného múzea v rokoch 1972-73 v Palárikove. Múzeum 19, 1974, 41-44.

Paulík 1976a - J. Paulík: Dve nové mohyly z mladšej doby bronzovej na juhozápadnom Slovensku. Archeologické rozhledy 28, 1976, 369-373, 475-477.

Paulík 1976b-J. Paulík: Keltské hradisko Pohanská v Plaveckom Podhradí. Fontes Archeologického ústavu Slovenského národného múzea v Bratislave 3. Bratislava 1976.

Paulík 1996 - J. Paulík: Železný nôž z Marianky. Zborník SNM 90. Archeológia 6, 1996, 43-56.

Paulík/Zachar 1975 - J. Paulík/L. Zachar: Kultový objekt a hroby z doby laténskej v Palárikove. Slovenská archeológia 23, 1975, 283-332.

Pieta 1983 - K. Pieta: Halštatské výšinné sídliská v Liptove. Archeologické rozhledy 35, 1983, 39-49, 119.

Pieta 2008 - K. Pieta: Keltské osídlenie Slovenska. Mladšia doba laténska. Archaeologica Slovaca Monographiae. Studia 11. Nitra 2008.

Pieta/Veliačik 2014 - K. Pieta/L. Veliačik: Pozoruhodné depoty zo Sklabinského Podzámku. Studia Archaeologica Brunensia 19, 2014, 5-26.

Repka 2014 - D. Repka: Pohrebiská z doby laténskej na Slovensku. Stav bádania. Študijné zvesti Aú SAV 56, 2014, 23-54.

Stegmann-Rajtár 2014 - S. Stegmann-Rajtár: Obrovská mohyla doby halštatskej v Regöly (Zadunajsko). Posvätné miesto rituálnych praktík a uctievania predkov? In: J. Čižmářová/N. Venclová/G. Březinová (ed.): Moravské křižovatky. Střední Podunají mezi pravěkem a historií. Brno 2014, 99-116.

Struhár 2014 - V. Struhár: Využívanie jaskýň a skalných dutín v období keltského osídlenia Slovenska. In: Kelti na Slovensku. Zborník z konferencie 2014. Martin 2014, 25-37.

Szabó/Tankó 2012 - M. Szabó/K. Tankó: La nécropole celtique à Ludas - Varjú-dűlő. In: M. Szabó (dir.): La nécropole celtique à Ludas - Varjú-dülő. Budapest 2012, 9-152.

Rukopis prijatý 25. 11. 2021

Summary translated by Viera Tejbusová

PhDr. Vladimír Mitáš, PhD.

Archeologický ústav SAV

Akademická 2

SK - 94921 Nitra

vladimir.mitas@savba.sk
Šaldová 1971 - V. Šaldová: Pozdně halštatské ploché hroby v západních Čechách a jejich vztah k současným mohylám. Pohřebiště Nynice a Žákava-Sváreč. Památky archeologické 62, 1971, 1-134.

Šiška 1981 -S. Šiška: Nové nálezy z povodia Bodvy. AVANS 1980, 1981, 289-291.

Tankó 2015 - K. Tankó: Celtic Burials from the Prehistoric Kurgan of Kiszombor C. In: L. Borhy/K. Tankó/K. Dévai (dir.): Studia Archaeologica Nicolae Szabó LXXV Annos Nato Dedicata. Budapest 2015, 267-279.

Točík/Paulík 1979 - A. Točík/J. Paulík: Mohyla z mladšej doby bronzovej a kostrové pohrebisko z 11. storočia v Čápore. Slovenská archeológia 27, 1979, 87-124.

Tomedi 2002 - G. Tomedi: Das hallstattzeitliche Gräberfeld von Frög. Die Altgrabungen von 1883 bis 1892. Archaeolingua 14. Budapest 2002.

Trefný/Jiráň a kol. 2012 - M. Trefný/L. Jiráň a kol.: Lužické pohřebiště v Chodounech u Roudnice nad Labem. Praha Roudnice nad Labem 2012.

Veliačik/Kujouský/Romsauer 2008 - L. Veliačik/R. Kujovský/ P. Romsauer: Hradisko lužickej kultúry v Sklabinskom Podzámku. AVANS 2006, 2008, 172, 173.

Veliačik/Srnka/Valo 2002 - L. Veliačik/F. Srnka/J. Valo: Hradisko Krivín v Rybníku. Študijné zvesti AÚ SAV 35, 2002, 27-44.

Venclová 2008 - N. Venclová (ed.): Archeologie pravěkých Čech 7. Doba laténská. Praha 2008.

Vlčková 2002 - J. Vlčková: Encyklopedie keltské mytologie. Praha 2002.

Waldhauser 1992 - J. Waldhauser: Laténská spona z hory Oblík v Poohří. Archeologické rozhledy 44, 1992, 467, 468.

Waldhauser 1999 - J. Waldhauser: Aktivity Keltů na pohřebištích a sídlištích doby bronzové v Pojizeří. Archeologie ve středních Čechách 3, 1999, 163, 164.

Waldhauser 2001 - J. Waldhauser: Encyklopedie Keltů v Čechách. Praha 2001.

Waldhauser 2002 - J. Waldhauser (s př́íspěvkem Michala Lutovského): Semín a Trosky. Problematika laténských struktur a lokalit. Archeologie ve středních Čechách 6, 2002, 325-350.

Waldhauser 2012 - J. Waldhauser: Aktivity Keltů v "horském" terénu Českého středohoří. Archeologie ve středních Čechách 16, 2012, 285-296.

Waldhauser/Koldová 2006 - J. Waldhauser/K. Koldová: Mimořádné aktivity Keltů na skalním útvaru Sokolka v Pojizeří. Archeologie ve středních Čechách 10, 2006, 555-598.

Wieland 2012 - G. Wieland: Besondere Orte. "Naturheilige" Plätze. In: R. Röber (Hrsg.): Die Welt der Kelten. Zentren der Macht - Kostbarkeiten der Kunst. Ostfildern - Konstanz 2012, 277-284.

Dr. h. c. prof. PhDr. Václav Furmánek, DrSc.

Archeologický ústav SAV

Akademická 2

SK - 94921 Nitra

vaclav.furmanek@savba.sk 


\title{
The Celts' Activities at Sites of the Urnfield Period in Slovakia
}

\author{
Vladimír Mitáš - Václav Furmánek
}

SUMMARY

The article presents finds of material culture from the La Tène period which document activities of the Celts at the sites from the Urnfield period in Slovakia. First of all, there are sporadically iron artifacts from the areas of cremation burial grounds and from stone constructions of the Kyjatice culture's burials in the south of central Slovakia. These artifacts were reliably archaeologically identified at the systematically excavated cremation burial grounds of the South-eastern Urnfield cultures in Cinobaňa (Poltár district), Radzovce (Lučenec district) and probably also during the revision excavation of the burial ground in the area of Babinec (Rimavská Sobota district). Nevertheless, La Tène material culture (metal and glass artifacts and pottery) was found at other cremation burial grounds (mostly of tumulus type) and in tumuli of the Urnfield cultures in western Slovakia. Bronze and iron artifacts, fragments of glass bracelets, pottery and rarely also Celtic coins also come from the upland sites and hillforts from the Late Bronze Age to the Hallstatt period in several regions of Slovakia - Katova skala site in the area of Sklabinský Podzámok, Tureň site in the area of Vítkovce, Zádielske hradisko hillfort (altitudes 553-600) in the area of Háj, Hradová in the urban area of Tisovec, Zámok in the area of Málinec, Pohanský vrch (Pohanský hrad) in the area of Kotmanová, Krivín in the area of Rybník, etc. As for the above-mentioned sites, it is probable that the determining factor for use of these sites by the Celts was mainly terrain configuration and their strategical location or associated prospecting activities, etc. The site of Vyšná Pokoradz (currently part of Rimavská Sobota) is a special case. Amateur excavations carried out as early as the $19^{\text {th }}$ century showed that it is one of the important sites of the South-eastern Urnfields documented by a settlement, cremation burial ground and hoards of bronze artifacts. Artifacts from the La Tène period come from the site too and Celtic coins occur as well. However, the mutual relations of prehistoric features and La Tène finds

Fig. 1. Cinobaňa, Jarčanisko site. 1-3 - hoard (part of hoard?) of iron artifacts from the La Tène period from the cremation burial ground; 4, 5 - find contexts of the artifacts from the depot (edited after Furmánek/ Mitáš 2014).

Fig. 2. Cinobaňa, Jarčanisko site. 1, 2 - characteristic artifacts from the La Tène period from the cremation burial ground (edited after Furmánek/Mitáš 2014); 3 - find context of the iron fibula; 4 - location of discovery of the fibula in the area of the burial ground.

Fig. 3. Cinobaňa, Jarčanisko site. 1-9 - selected iron artifacts from the La Tène period from the cremation burial ground, finds from excavation seasons 2008-2011 are undefinable after such a long time. Unfortunately, the relation of the Hallstatt and La Tène burials at the burial ground in Drňa (Rimavská Sobota district) cannot be defined either. In spite of that, the La Tène finds from the burial grounds' areas at the sites of Cinobaňa, Jarčanisko site, and Radzovce, Monosa site, are of the greatest importance for the topic of the Celts' activities at Slovak Urnfield culture sites. Secondarily disturbed cist burials or stone cists in which the grave goods as well as burned bones were manipulated with were identified in Cinobaňa. Were these burials disturbed by the Celts? Activities of a similar character are most probably suggested by the La Tène material at the tumulus burial grounds of the Lusatian culture from the Late Bronze Age in western and northwestern Slovakia (Krásna Ves, Sklabinský Podzámok). The unique Celtic burials in the Late Bronze Age (Cabaj-Cápor, western Slovakia?) and Early Iron Age (Včelince, southern central Slovakia) tumuli or in the tumulus-like natural shape (Ratka, southern central Slovakia) are special. The Celtic sacrificial ground with a group of burials with exceptional inventory in the body of a tumulus from the Late Bronze Age at the site of Palárikovo II (western Slovakia) is unique. We suppose that the Celts' activities at the sites from the Urnfield period and possibly from the Hallstatt period might have been ritual - veneration of the dead or other religious activities (mostly at burial grounds, burial grounds with tumuli and separately standing tumuli) as well as profane - landscape prospecting, use of strategically important sites, refuges, mountain tracks, seasonal pastures, etc. (as for upland sites and hillforts). Nevertheless, when analysing the finds from the upland sites, we cannot ignore ritual activities or combinations of non-profane and profane activities at the sites. It is obvious that the visible prehistoric relics in the landscape were intensely perceived by the Celts. They associated some of the relics with their past. The article explains it by the so-called material memory of communities.

(edited after Furmánek/Mitáš 2014); 10-13 - find contexts of selected iron artifacts. Scale: $1-7$, 9; without scale -8 .

Fig. 4. Cinobaňa, Jarčanisko site. Miniature iron axe. 1 condition of the artifact after its discovery; 2 - condition of the artifact after conservation (after Furmánek/ Mitáš 2010a).

Fig. 5. Cinobaňa, Jarčanisko site. 1-3 - iron sponge and slag from the cremation burial ground (edited after Furmánek/Mitáš 2010a; 2011a); 4, 5 - burials 25/08 and 217/11(12). Scale: $a-1 ; b-2,3$.

Fig. 6. Cinobaňa, Jarčanisko site. 1-6 - Kyjatice culture burials with disturbed cists and inventory (edited after Furmánek/Mitáš 2011a). 
Fig. 7. Radzovce, Monosa site. 1 - unique iron knife from the stone construction of burial 729/73 (after Furmánek 2010); 2 - Kyjatice culture burial 729/73 (after Furmánek/ Mitáš/Budaváry 2016).

Fig. 8. Material documenting Celtic activities at the sites from the Urnfield period in Slovakia. 1 - Palárikovo II; 2-4 - Sklabinský Podzámok, 'ústie Kantorksej doliny' site; 5, 6 - Sklabinský Podzámok, Katova skala site; 7, 8 - Rybník, Krivín site; 9, 10, 12 - Málinec, Zámok site; 11 - Vítkovce, Tureň site; 13 - Krásna Ves, Pieskovisko site. 1, 5-10, 12 after Pieta 2008; 2-4 after Horńák 2005; 11 after MiroššayoválJavorský 1986; 13 after BudinskýKrička/Veliačik 1986. Scale: a - 1; b - 2-12; without scale - 13 .

Fig. 9. Včelince, Halomszer site. Inventory of the La Tène burial from the prehistoric tumulus mound (edited after Furmánek/Marková 1994). Scale: a - 1-4; b-5.

Fig. 10. Tisovec, Hradová site. Material from the La Tène culture (Bartík/Čambal 2014, pl. I).

Fig. 11. Cinobaňa. Complex of archaeological sites. Legend: a - settlement from the Urnfield and La Tène periods; b - burial ground from the Urnfield period with evidence of La Tène activities; $\mathrm{c}$ - hillfort from the Late Bronze Age.
Fig. 12. Cinobaňa, Jarčanisko site. Occurrence of artifacts from the La Tène period at the cremation burial ground of the Urnfield cultures (area excavated in 2008-2013; burial 2/07 was located outside this area). Legend: a cremation burial; b - hoard of iron artifacts; c - iron fibula; $\mathrm{d}$-iron artifact or iron fragment; e - iron sponge and slag; $\mathrm{f}$ - fragment of pottery.

Fig. 13. Sites of the Urnfield and Hallstatt periods documenting Celtic activities (in alphabetical order). 1 - Babinec, 'northeast area of village' site; 2 -Cabaj-Čápor, part Čápor, Pri kopci site; 3 - Cinobaňa, Jarčanisko site; 4 - Chotín V, Sashegy site; 5 - Kotmanová, Pohanský hrad (Pohanský vrch) site; 6 - Krásna Ves, Pieskovisko site; 7 - Marianka, Barania lúka site; 8 - Málinec, Zámok site; 9 - Palárikovo II, Kopcová remíza site; 10 - Radzovce, Monosa site; 11 - Ratka, part Malá Ratka, 'right bank of Babský potok' site; 12 - Rybník, Krivín site; 13 - Sklabinský Podzámok, 'ústie Kantorskej doliny' site; 14 - Sklabinský Podzámok, Katova skala site; 15 - Stará Bašta, 'surroundings of Pohanský hrad' site; 16 - Tisovec, Hradová site; 17-Včelince, Halomszer site; 18 - Vítkovce, Tureň site. Legend: a - cremation burial ground; $b$ - cremation burial ground with tumuli; c-separately standing tumulus or tumulus-like natural shape; $\mathrm{d}$ - hillfort or upland site. 
